\title{
BUILD BACK BETTER
}

WHAT IS IT, AND WHAT SHOULD IT BE?

Ilan Noy, Benno Ferrarini, and Donghyun Park

NO. 600

December 2019
ADB ECONOMICS WORKING PAPER SERIES 


\section{ADB Economics Working Paper Series}

\section{Build Back Better: What Is It, and What Should It Be?}

Ilan Noy, Benno Ferrarini, and Donghyun Park

No. 600 | December 2019
Ilan Noy (ilan.noy@vuw.ac.nz) is Chair in the Economics of Disasters and Professor of Economics at the Victoria University of Wellington. Benno Ferrarini (bferrarini@adb. org) and Donghyun Park (dpark@adb.org) are Principal Economists in the Economic Research and Regional Cooperation Department of the Asian Development Bank.

This paper was prepared as background material for the Asian Development Outlook 2019 theme chapter on "Strengthening Disaster Resilience."

We thank Diana De Alwis for her excellent assistance in collecting and collating the data used in this paper. 
(C) 2019 Asian Development Bank

6 ADB Avenue, Mandaluyong City, 1550 Metro Manila, Philippines

Tel +632 8632 4444; Fax +63286362444

www.adb.org

Some rights reserved. Published in 2019.

ISSN 2313-6537 (print), 2313-6545 (electronic)

Publication Stock No. WPS190583-2

DOI: http://dx.doi.org/10.22617/WPS190583-2

The views expressed in this publication are those of the authors and do not necessarily reflect the views and policies of the Asian Development Bank (ADB) or its Board of Governors or the governments they represent.

ADB does not guarantee the accuracy of the data included in this publication and accepts no responsibility for any consequence of their use. The mention of specific companies or products of manufacturers does not imply that they are endorsed or recommended by ADB in preference to others of a similar nature that are not mentioned.

By making any designation of or reference to a particular territory or geographic area, or by using the term "country" in this document, $A D B$ does not intend to make any judgments as to the legal or other status of any territory or area.

This work is available under the Creative Commons Attribution 3.0 IGO license (CC BY 3.0 IGO)

https://creativecommons.org/licenses/by/3.0/igo/. By using the content of this publication, you agree to be bound by the terms of this license. For attribution, translations, adaptations, and permissions, please read the provisions and terms of use at https://www.adb.org/terms-use\#openaccess.

This CC license does not apply to non-ADB copyright materials in this publication. If the material is attributed to another source, please contact the copyright owner or publisher of that source for permission to reproduce it. $\mathrm{ADB}$ cannot be held liable for any claims that arise as a result of your use of the material.

Please contact pubsmarketing@adb.org if you have questions or comments with respect to content, or if you wish to obtain copyright permission for your intended use that does not fall within these terms, or for permission to use the ADB logo.

Corrigenda to ADB publications may be found at http://www.adb.org/publications/corrigenda.

Notes:

In this publication, “\$” refers to United States dollars.

ADB recognizes "China” as the People's Republic of China.

The ADB Economics Working Paper Series presents data, information, and/or findings from ongoing research and studies to encourage exchange of ideas and to elicit comment and feedback about development issues in Asia and the Pacific. Since papers in this series are intended for quick and easy dissemination, the content may or may not be fully edited and may later be modified for final publication. 


\section{CONTENTS}

TABLES AND FIGURES

ABSTRACT $v$ V

$\begin{array}{ll}\text { I. INTRODUCTION } & 1\end{array}$

II. THE TYPOLOGY OF POSTDISASTER RECOVERY 2

III. LONG-TERM MACROECONOMIC BUILD BACK BETTER 4

IV. $\quad$ BUILD BACK BETTER AT THE LOCAL LEVEL

A. Incomes, Asset Prices, Productivity, and Sectoral Employment 5

B. Demography and Human Capital (Health and Education) 6

C. Social Capital and Institutions 8

V. THE CASE OF SRI LANKA AFTER THE 2004 TSUNAMI 9

A. What Can We Learn from the Macroeconomic Data? 10

B. What Do the Household Surveys Tell Us?

C. What Can We Conclude about Build Back Better in Sri Lanka after 2004? 21

VI. THE 2008 WENCHUAN EARTHQUAKE 22

A. What Can We Learn from the Macroeconomic Provincial Data? 23

B. What Do the Household Surveys Tell Us? 28

VII. POLICY CONCLUSIONS ABOUT BUILD BACK BETTER 29
A. Build Back Safe
29
B. Build Back Fast
29
C. Build Back Fair
30
D. Build Back Potential 30 


\section{TABLES AND FIGURES}

\section{TABLES}

$1 \quad$ Tsunami Damage in Sri Lanka 10

2 Percentage Share of Gross Domestic Product by Main Service Sector Categories 13

3 Impact of Tsunami on Household Income and Consumption 20

$4 \quad$ Impact of Tsunami on Household Consumption by Type of Consumption 20

$5 \quad$ Income Variation Depending on Wealth and Damage Intensity 20

6 Consumption Variation Depending on Wealth and Damage Intensity 21

$7 \quad$ Affected Areas and Damage $\quad 22$

$8 \quad$ Sum of Direct Damage and Losses 23

\section{FIGURES}

1 Typology of Disaster Impacts 2

2 Districts Affected by the Tsunami 9

3 Growth of Per Capita Gross Domestic Product at Constant Prices 11

$4 \quad$ Agriculture and Industry Sector Contribution to Gross Domestic Product 11

$5 \quad$ Percentage Share of Gross Domestic Product by Fishery Types at Constant 2002 Prices 12

6 Percentage Share of Gross Domestic Product by Main Industry Sector Categories 13 at Constant 2002 Prices

$7 \quad$ Inflation and Unemployment 14

8 Total Government Expenditure 14

9 Current Account Balance $\quad 15$

10 Personal Remittance Growth Rate 16

11 Foreign Aid 16

12 Damage at District Level 18

13 Income across Tsunami (Treatment) and Nonaffected (Control) Households 18

14 Consumption across Tsunami (Treatment) and Nonaffected (Control) Households 19

15 Per Capita Gross Regional Product in Sichuan 24

16 Value Added by Sectors in Sichuan 24

17 Total Value of Commercial Buildings Sold in Sichuan 25

18 Investments in Residential Buildings in Sichuan $\quad 25$

19 Building Construction by Floor Space in Sichuan 26

20 Consumer Price Index by Commodity Type 27

$21 \quad$ Sichuan Government Budgetary Expenditure $\quad 27$

22 Resident Population in Sichuan 28 


\begin{abstract}
The long-term economic consequences of catastrophic disasters are poorly understood. This lacuna is surprising since the long-term effects may be much more important than the short-term emergency phase. In contrast, the policy literature is full of aspirational plans to "build back better" (BBB)-a recovery that leads to improvements above and beyond the predisaster status quo. BBB is clearly multidimensional, but the focus here is the assessment of economic BBB. We first delve into two wellknown BBB cases-Sri Lanka after the 2004 Indian Ocean tsunami and Sichuan province in the People's Republic of China after its 2008 earthquake. Following that analysis, the central objective of our paper is to propose a more precise and concrete definition of economic BBB. To do so, we propose four criteria against which one should evaluate BBB policies: safety, speed, fairness (inclusiveness), and socioeconomic potential. We conclude by describing each of the four criteria in greater detail.
\end{abstract}

Keywords: build back better, disaster, economic impact, long run, recovery

JEL codes: $\mathrm{H} 54, \mathrm{Q} 54$ 
"Would you tell me, please, which way l ought to go from here?"

"That depends a good deal on where you want to get to," said the Cat.

"I don't much care where-" said Alice.

"Then it doesn't matter which way you go," said the Cat.

"-so long as I get SOMEWHERE," Alice added as an explanation.

"Oh, you're sure to do that," said the Cat, "if you only walk long enough."

(Alice in Wonderland by Lewis Carroll, Chapter 6)

\section{INTRODUCTION}

Almost all the measurement, empirical estimation, and theoretical modeling of disaster risk focuses on the immediate economic impact of disasters triggered by natural hazards such as tropical storms, earthquakes, or droughts. Even more effort is expanded outside economics, for example on the science of natural hazards, to improve our understanding of their causes and likely occurrences, our ability to predict them, and our knowledge of the ways they affect us. In comparison, relatively little research attention has been directed toward the longer-term consequences of these events (see section IV). This is true for economic long-term trajectories, but it is equally true for cultural and social effects, public health effects, and even geospatial effects such as where people choose to live and work. This lack of attention to long-term effects is puzzling since these effects, which can last decades, are likely more important than the short-term postdisaster emergency phase.

In contrast to these lacunae, the policy literature is full of largely aspirational plans to "build back better" (BBB) and facilitate a recovery from a disaster that is not only complete but that leads to improvements above and beyond the predisaster status quo, maybe even improvements that would have been difficult to achieve in the absence of disasters. Although BBB is multidimensional, this paper focuses on economic dimensions rather than other dimensions that may be relevant for a fuller assessment of long-term effects. For example, here we are not evaluating the long-term environmental impacts-for example, ecological diversity-or, at the other end of the consequence spectrum, the long-term psychological impact of catastrophes on emotional well-being of victims. While environmental and psychosocial BBB are important, noneconomic BBB is outside the scope of our paper. Furthermore, the scope of our paper is limited to economic trajectories that have been measured or can be measured. We recognize that this limits our discussion, and that some equally important but unmeasured and/or unmeasurable effects are researched in the qualitative literature in disciplines such as geography and sociology.

In sections II-IV, we examine the existing body of knowledge about economic BBB. In the following two sections, we take an in-depth look at two Asian case studies-Sri Lanka after the 2004 Indian Ocean tsunami (section V) and the province of Sichuan, in the People's Republic of China (PRC), after its 2008 earthquake (section VI). For reasons we describe below, we consider both as potential poster children for economic BBB.

However, in section VII we argue that BBB is often so vaguely specified that policy makers and analysts can often declare their aspiration to BBB as fulfilled, even if the long-term outcome is less than an unalloyed success. BBB is akin to the observation in Lewis Carroll's Alice in Wonderland, made 
by the Cheshire Cat to Alice, that she is sure to arrive at her destination as long as she does not have one. Maybe appropriately for our analogy with BBB, the Cheshire Cat observes that Alice will "get SOMEWHERE" if she walks "long enough."

In trying to define economic BBB more precisely and concretely, we propose a new set of criteria for economic BBB:

- build back safe

- build back fast

- build back fair

- build back potential

We briefly describe each criterion and conclude with some final thoughts for future research.

\section{THE TYPOLOGY OF POSTDISASTER RECOVERY}

A disaster occurs when a hazard interacts with an exposed and vulnerable population, causing harm to people and/or damaging physical assets such as property or infrastructure. Hazards include natural hazards (such as hurricanes and earthquakes); humanmade hazards (such as industrial failures and nuclear meltdowns); or some combination of the two (e.g., the severe acute respiratory syndrome, or SARS, epidemic). Some disasters take place instantly and abruptly while others take place over a longer span of time. It is important to note that in and of themselves hazards are not disasters. Rather, it is a society's failure to cope with a hazard that turns a hazard into a disaster. Here, we focus only on disasters that are triggered by natural hazards although we refrain from using the term natural disaster.

A standard framework classifies disaster impact into direct impact versus indirect impact. Direct costs encompass damage to physical and natural assets, such as factories and farmland, and of course, loss of human life (i.e., mortality) and injury and illness (i.e., morbidity). Indirect losses denote the adverse effect of the disaster on economic activity (see Figure 1). There is also a distinction between short-run losses and long-run losses.

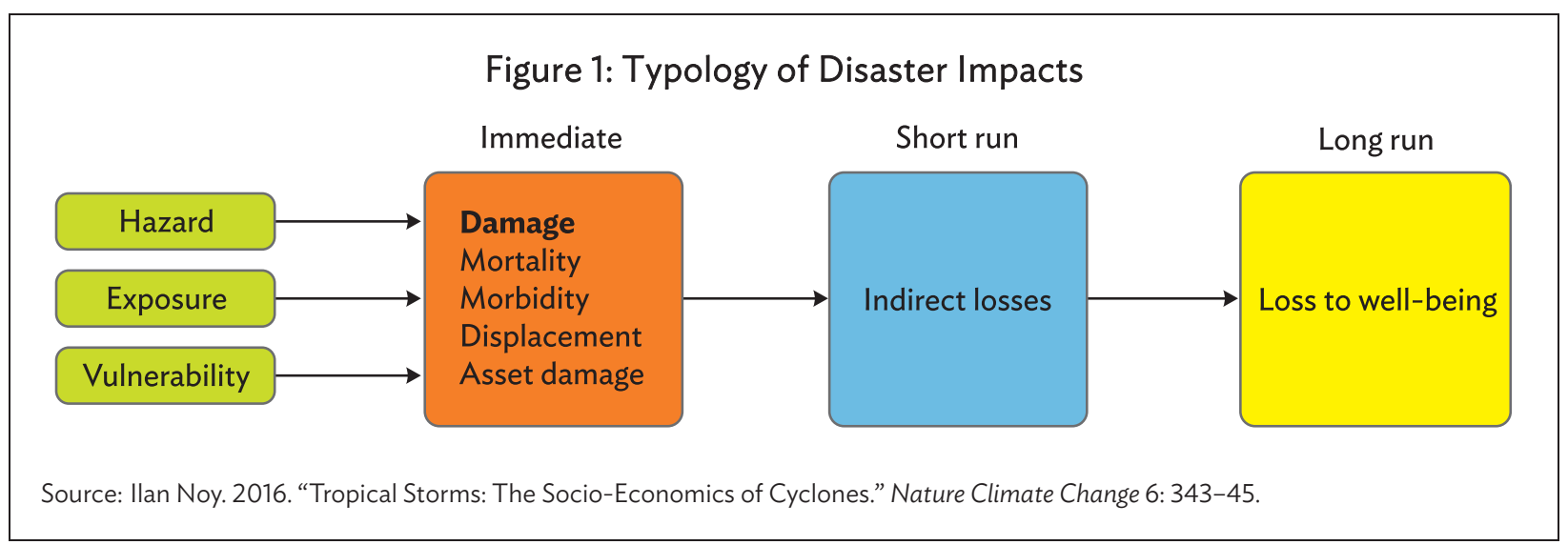


The extent of damage is one important determinant of the long-term recovery process. Due to differences in vulnerability, high-income countries generally suffer fewer human casualties but larger material damage than other countries. Furthermore, the material damages tend to be smaller relative to gross domestic product (GDP). As such, if one examines the translation from damage to indirect losses, it is not difficult to understand why we expect indirect losses to be much higher in low- and middle-income countries. Such unequal impacts are not only observed across countries, but within countries as well.

One of the most significant disparities is between the rural and urban population. Governments have to decide how to allocate limited resources between cities and the countryside. They often favor urban areas, which have higher densities of people and productive assets, and rural areas suffer as a result. This is especially true for meteorological and hydrological disasters. Rural areas can therefore be more exposed to these, while they are a lot less exposed to seismic disasters, which pose the highest risk to built-up areas. The urban-rural divide is only one of many distinctions that shape the trajectory of disaster damages as well as the trajectory of the subsequent recovery process.

Countries, regions, cities, and even households not only differ in terms of the impact they suffer, but also their ability to bounce back and recover. In the short run, access to resources, which may come from existing wealth, borrowing, insurance payments or foreign transfers, for reconstruction is the decisive factor. Please refer to Klomp and Valckx (2014) and Lazzaroni and van Bergeijk (2014) for an excellent review of the short-run macroeconomic recovery literature.

Self-insurance against adverse shocks, or precautionary savings, is one possible solution. Precautionary savings, which tend to be inadequate according to available evidence, are an important source of funding for recovery. Such savings also lead to further income disparity, as they help the better off, who can afford to save more, achieve better outcomes.

In the absence of insurance, the government often steps in and provides direct transfers to disaster victims. Another major source of resources for recovery and resilience is access to credit. For instance, Sawada and Shimizutani (2008) find that households with better access to credit were better able to continue to finance their consumption. We have little evidence on these channels in middleand low-income countries, as household surveys rarely delve into detail about household debt and borrowing within the context of postdisaster recovery dynamics (see, for example, Sawada and Takasaki 2017, and papers therein). McDermott (2012) finds that access to credit helps to build resilience by enabling households to continue to invest in education. Lack of credit exacerbates inequality by hindering the recovery process of marginalized groups. Finally, lack of credit harms businesses in affected communities as well.

Local social and political institutions also matter. Raschky (2008) and Cavallo et al. (2013) present evidence that highlights the importance of institutions in disaster recovery. Aldrich (2012) argues that social capital is potentially the most vital determinant of the ability of communities to recover. Examining the postdisaster experiences after the Tokyo and Kobe earthquakes, as well as those following the 2004 Indian Ocean tsunami in Tamil Nadu and the 2005 Hurricane Katrina in New Orleans, he finds that communities with strong social networks (e.g., friends, family, neighborhood ties) were significantly more efficient at sharing crucial information and providing financial and physical assistance to those in need, and also were better able to stem the flow of people and resources out of the area. 
We should note that disasters can generate indirect benefits. For example, the aftermath of a disaster sometimes brings about a reconstruction boom; this boom can, in turn, lead to increasing wages in this sector that can even spill over to increases in wages in other sectors. More generally, reconstruction can act like a standard Keynesian fiscal stimulus by increasing central government spending in the disaster area. Indirect damage and benefits can have large long-term effects, which means they may shape the long-term recovery process.

\section{LONG-TERM MACROECONOMIC BUILD BACK BETTER}

According to the classical (or neoclassical) view of disasters, they only have limited economic effect in the long run. Both Adam Smith and John Stewart Mill described this as a surprising and rapid return to normality (Adam 1776, Mill 1896). A significant amount of empirical evidence supports this traditional view. In this context, Cavallo et al. (2013) fail to find any significant long-run national-level effects of disasters for up to 10 years after the event. Nevertheless, they uncover a few cases when a disaster entailed dramatic institutional changes. Their prototypical example is the Iranian earthquake of 1978 that was followed within a year by the Islamic Revolution, a subsequent catastrophic economic collapse, armed conflict, and steep declines in per capita incomes.

Even papers that find a macroeconomic effect find the effect to be weak and confined to some low-income countries (duPont and Noy 2018). Loayza et al. (2012) find that developing countries are more vulnerable to disasters than advanced economies. In addition, they find that severe floods are harmful but moderate floods can be beneficial. Fomby et al. (2013) also find that uniquely among disasters, floods can benefit developing nations. Felbermayr and Gröschl (2014) find no positive effects, but their analysis also seems to suggest that it is the worst disasters that impact GDP per capita negatively, while evidence in relation to the less dramatic events is less clear. Unlike most studies, Skidmore and Toya (2002), in cross-sectional estimations, uncover positive long-run effects. More specifically, according to their evidence, human capital grows, and total factor productivity improves in countries prone to disasters. Countries facing greater disaster risk, especially climactic disaster risk, tend to grow faster.

The destruction associated with disasters can improve the disaster area's economic outlook by bringing about beneficial change. In particular, the destruction of old infrastructure opens the door to invest in new and better infrastructure. In principle, improved infrastructure can promote productivity growth. This is the creative destruction scenario of locations being built-back-better in the long run.

However, the evidence for such a positive outcome, at the national level, is quite thin. The few papers that find supportive evidence are typically limited in scope, and the possible long-run positive effects are limited to moderate disasters in higher-income areas (e.g., Cuaresma, Hlouskova, and Obersteiner 2008) or to events in which the postdisaster assistance was unusually generous (see section $\vee$ for more detail).

On the other hand, evidence suggests that the recovery of poor countries can be painfully slow after severe disasters. Small island developing states (SIDS) are at highest risk due to a hazard's relatively large footprint on their limited size, remoteness, and lack of economic diversification. These factors magnify the total loss and hinder long-term recovery prospects. There is a dearth of evidence available about the long-term postdisaster trajectories in SIDS. One can trace this lack of evidence to two factors: (i) a general underinvestment in research on SIDS; and (ii) the difficulty in identifying any 
evidence of long-term impact since the economies of SIDS are highly volatile. This volatility prevents researchers from identifying the counterfactual no-disaster scenario that enables one to identify a disaster's long-term impact. Haiti, an SIDS, suffered the worst recent catastrophe in 2010. The catastrophe was so severe that it clearly harmed Haiti's long-term economic development prospects (Best and Burke 2019).

\section{BUILD BACK BETTER AT THE LOCAL LEVEL}

As there is less evidence on very long-term recovery trajectories in low- and middle-income countries, the evidence discussed in this section comes mostly from observations made in high-income countries. The evidence of very long-term or permanent effects of disasters are sometimes identified at the local level. In particular, existing research has uncovered quantitative evidence of permanent changes in incomes and asset prices, permanent shifts in sectors of economic activity, and long-term institutional, social, and even cultural shifts that were triggered by the disaster. Country-level data do not show many of these effects since these dynamics only affect those regions that were directly affected by the disaster. We focus on three related areas that appear to be the main channels through which disasters can have very long-term local impacts: (i) incomes, asset prices, productivity, and sectoral employment; (ii) demography and human capital - that is, health and education; and (iii) institutions and social capital.

\section{A. Incomes, Asset Prices, Productivity, and Sectoral Employment}

As we already observed, evidence of creative destruction is primarily confined to moderate floods. Furthermore, the evidence indicates that for the most part, any identified improvement is not due to technological innovation or implementation of BBB policies, but rather governmental policies to increase local resilience through increased investment. In addition, even when there is a more than $100 \%$ macroeconomic recovery, richer households tend to cope better with the disaster and achieve superior long-run outcomes.

According to Hornbeck and Keniston (2017), the Great Boston Fire of 1872 was linked to significant long-run benefits. They argue that reconstruction of individual properties led to positive externalities - that is, benefits to neighboring properties - that were large enough to compensate, in the aggregate, for much of the damage caused by the fire. As such, the fire sped up a process of urban renewal that would have probably happened anyway, but because much of the benefit is external to the property owners, it would have taken much longer.

In another study by Hornbeck and Naidu (2014), the Great Mississippi Flood of 1927 led to the modernization of agriculture in affected regions. A contributing factor was the outward migration of black sharecroppers after the flood. Intuitively, the resulting shortage of workers pushed farmers toward new technologies. Areas less affected by the flood and its consequent migration adopted the new technologies to a lesser extent and enjoyed fewer long-term improvements in productivity. Boustan et al. (2017) conduct a more comprehensive investigation using a large spatial and temporal dataset of United States (US) counties to analyze intercounty out-migration following catastrophic events.

In addition, there is evidence that disasters can significantly affect household income in the long term. duPont and Noy (2015) find that, more than 10 years after the Kobe earthquake, the GDP per capita for Hyogo prefecture, which includes Kobe, fell by $12 \%$ relative to the counterfactual 
scenario of no earthquake. Cole et al. (2019) analyzed specific production facilities in Kobe and found that heavily damaged plants were more likely to remain closed up to 7 years after the event. Furthermore, duPont et al. (2015) associate the postearthquake economic decline of Kobe with a sector shift from manufacturing to services that was triggered by the earthquake, and a shift in employment from Kobe to nearby Osaka.

In addition to loss of income, decline in asset prices is another piece of evidence of long-term economic decline. In particular, land prices are an informative bell weather. Hornbeck (2012) finds that the environmental damage resulting from the American Dust Bowl of the 1930s had long-term effects. The Dust Bowl caused large-scale displacement of people and permanently reduced the value of farmland by $30 \%$ in high-erosion areas (Dell, Jones, and Olken 2014). The decline in the value of farmland, often used as collateral, reduced access to credit. The disruption of finance, a vital ingredient for growth, prolonged the negative economic effects for 50 years.

\section{B. Demography and Human Capital (Health and Education)}

A large number of studies have focused on the impact of disasters on demographics, though relatively few attempt to identify these impacts in the long term. Disasters cause large displacements of populations. Hurricane Katrina, which inundated New Orleans in 2005, is one of the most prominent and intensely researched examples. There are plenty of other examples of out-migration as a result of a disaster, but the impact of these out-migrations is sometimes quite nuanced (e.g., Coffman and Noy 2012; Boustan, Kahn, and Rhode 2012). Smith and McCarty (1996) find that $11 \%$ of the 353,000 individuals displaced by Hurricane Andrew in August 1992 did not return home.

What happens to those that are permanently displaced? Deryugina et al. (2018) find that, on average, individuals who did not return home within 5 years of Hurricane Katrina earned more than their pre-Katrina incomes. Thus, if we focus narrowly on incomes, some people who were permanently displaced by the hurricane have benefited.

In lower-income countries, often only select members of households, rather than entire households, migrate away from the affected areas. According to Gröger and Zylberberg (2016), rural Vietnamese households mitigate the impact of disasters by sending family members to cities for work. Halliday (2012) finds a similar pattern in postearthquake El Salvador. However, both studies find that many migrants failed to return. Therefore, while migration benefited households, it reduced the disaster region's population, resulting in less economic activity.

There is also evidence that disasters can lead to migration into the affected region. This in-migration is usually motivated by two possible factors. The first is the spending associated with the recovery process, and the associated boom in construction. The second is that the recovery effort may lead to changes that make the affected area more attractive. For example, according to Husby et al. (2014), the regions hit by the 1953 North Sea flood of the Netherlands enjoyed population growth. This was largely due to government actions that improved disaster resilience, attracting outsiders to areas made safer by those actions. Similarly, focusing on disasters in the US during the early 20th century, Boustan et al. (2012) uncover evidence of inward migration to flood-prone areas. They attribute the inward migration to the engineering and construction work done by the Army Corps of Engineers to tackle future flooding. Whether this can be thought of as an example of BBB is less certain. For example, given the well-documented failure of the Army Corps of Engineers to maintain the levee system that protected New Orleans, and the unprecedented destruction of 2005 due to this 
failure, one might credibly argue that increases in population in flood-affected areas might turn out to be a bane rather than a boon.

Schultz and Elliott (2013) analyze US disasters and arrive at more nuanced conclusions about the effects of population movements on income distribution. They find that those who benefited from this influx of migrants, which expanded the population and economic activity, were the top deciles of the income distribution. In contrast, the poor benefited very little.

In the New Orleans case, some studies delved into the return behavior of displaced residents (Landry et al. 2007, Groen and Polivka 2010). Income emerges as a major factor in households' decision on whether or not to return to New Orleans. Richer households were more likely to return. Connection to the place played little role. According to Groen and Polivka (2010), among the various ethnic groups of the city, blacks were less likely to return. African American neighborhoods of New Orleans suffered disproportionately heavy damage. Paul (2005) argues that out-migration is not inevitable, and compensation for damage and assistance can convince inhabitants to stay, even in lowincome countries. He investigates this for Bangladesh.

Health and education are two additional channels through with disasters can potentially have long-lasting economic effects. There are only a handful of studies in this area, but they are worth noting since the impact on health and human development may generate very long-lasting effects. McDermott (2012) finds that limited access to credit can constrain human capital investment. Spencer, Polachek, and Strobl (2016) find negative effect on educational achievement, rather than number of years in school, in the Caribbean-a region highly exposed to hurricane risk. Cas et al. (2014) uncovered a similar effect on Indonesian children orphaned by the 2004 Indian Ocean tsunami; see also Rush (2018) for an investigation of a wider sample of smaller disasters in Indonesia. They find a more pronounced effect for older children, who completed fewer years of schooling. One possible explanation is that older children assume parental responsibilities, disrupting their education. Less education diminishes the long-term income earning potential of such children.

Most troubling is the study by Caruso and Miller (2015). Strikingly, they uncover evidence that children who were in utero during a catastrophic Peruvian earthquake acquire less education. More strikingly, they find that even the children of disaster-affected mothers-that is, mothers who were exposed in utero-also attain less education after several decades. Caruso (2017) replicated these extraordinary results for a much wider sample of Latin American disasters.

Of course, the educational attainment of affected individuals depends on their educational prospects before the event-for example, the quality of the local education system-and the changes triggered by the event. For instance, the case of New Orleans, where the education system was widely considered a failure before the hurricane, provides an interesting counterargument. Sacerdote (2012) finds that on average students who were forced to change schools performed better, although intriguingly this improved performance did not translate into a statistically observable increase in enrollment in tertiary education.

The literature on the health impacts of disasters typically focuses on the identifiable shortterm impacts of events. There is much literature on short-term health consequences; for example, Yonson (2018), but presumably, some of these identified short-term impacts may be persistent. For example, Currie and Rossin-Slater (2013) find that birth outcomes deteriorate when mothers are 
exposed to a hurricane even in the US, a country with a vastly better health system than in most lowand middle-income countries.

Most tragically persistent is mortality. There is scant literature on indirect deaths, or deaths beyond the direct deaths caused by disasters, suggesting that early public health support, especially for the elderly, is a crucial factor for reducing the indirect health effects of a disaster (Morita et al. 2017). For example, Japanese government records suggest about 1,600 indirect deaths occurred after the Fukushima nuclear meltdown in 2011. Similarly, a careful examination of death records suggests similarly high indirect mortality after Hurricane Maria hit Puerto Rico in 2017 (Kishore et al. 2018). In another example, Parida et al. (2018) uncover evidence that droughts and floods increased the prevalence of farmer suicides in India in recent decades. In general, in most cases, disasters have a negative impact on both education and health, which, in turn, has long-term implications for future income as well as personal well-being.

\section{Social Capital and Institutions}

Disasters can severely affect interpersonal relationships within societies-that is, social capital. Much of the previous microeconomic and behavioral research, almost all of it quite recent, has centered on whether the occurrence of a catastrophe changes risk perceptions, risk aversion, reciprocity, altruism, and trust within members of social groups and between different social groups. All of these have the potential to affect long-term economic trajectories, but no research has been done to identify such potential long-term impacts. The existing literature focuses instead on short-run changes to these different social aspects and yields very mixed evidence (e.g., Becchetti, Castriota, and Conzo 2017; Callen 2015; Cassar, Healy, and von Kessler 2017; Dussaillant and Guzmán 2014; and Yamamura 2016).

One last channel through which disasters might have very long-term impacts is through their effects on institutions. Cavallo et al. (2013) argue that long-term economic losses associated with disaster event is due to institutional change. As previously mentioned, they cite Iran after the country's 1978 earthquake as their prototypical example. Belloc, Drago, and Galbiati (2016) focus on the institutional dynamics generated by the earthquakes, which affected Italian city-states during the Middle Ages. Hanlon (2017) provides another historical example from the United Kingdom, where a sudden unnatural external shock, associated with the US Civil War and the disruption of the cotton trade, had persistent long-term impacts at the city level. 


\section{THE CASE OF SRI LANKA AFTER THE 2004 TSUNAMI}

The 2004 Indian Ocean earthquake lifted the ocean floor by more than 3 meters, triggering a catastrophic tsunami which took 226,000 lives and displaced at least 2 million people in a dozen countries (De Alwis and Noy 2019). In Sri Lanka, where the tsunami was completely unexpected, it hit 13 out of the country's 14 coastal districts (Figure 2). The death toll approached 35,500, and at least 1 million people lost their homes (Table 1). The tsunami inflicted serious damage on the infrastructure of Sri Lanka, which suffered total direct economic losses of $\$ 1.5$ billion or around $5 \%$ of the GDP (Government of Sri Lanka 2005).

Figure 2: Districts Affected by the Tsunami

NUMBER OF DEATHS

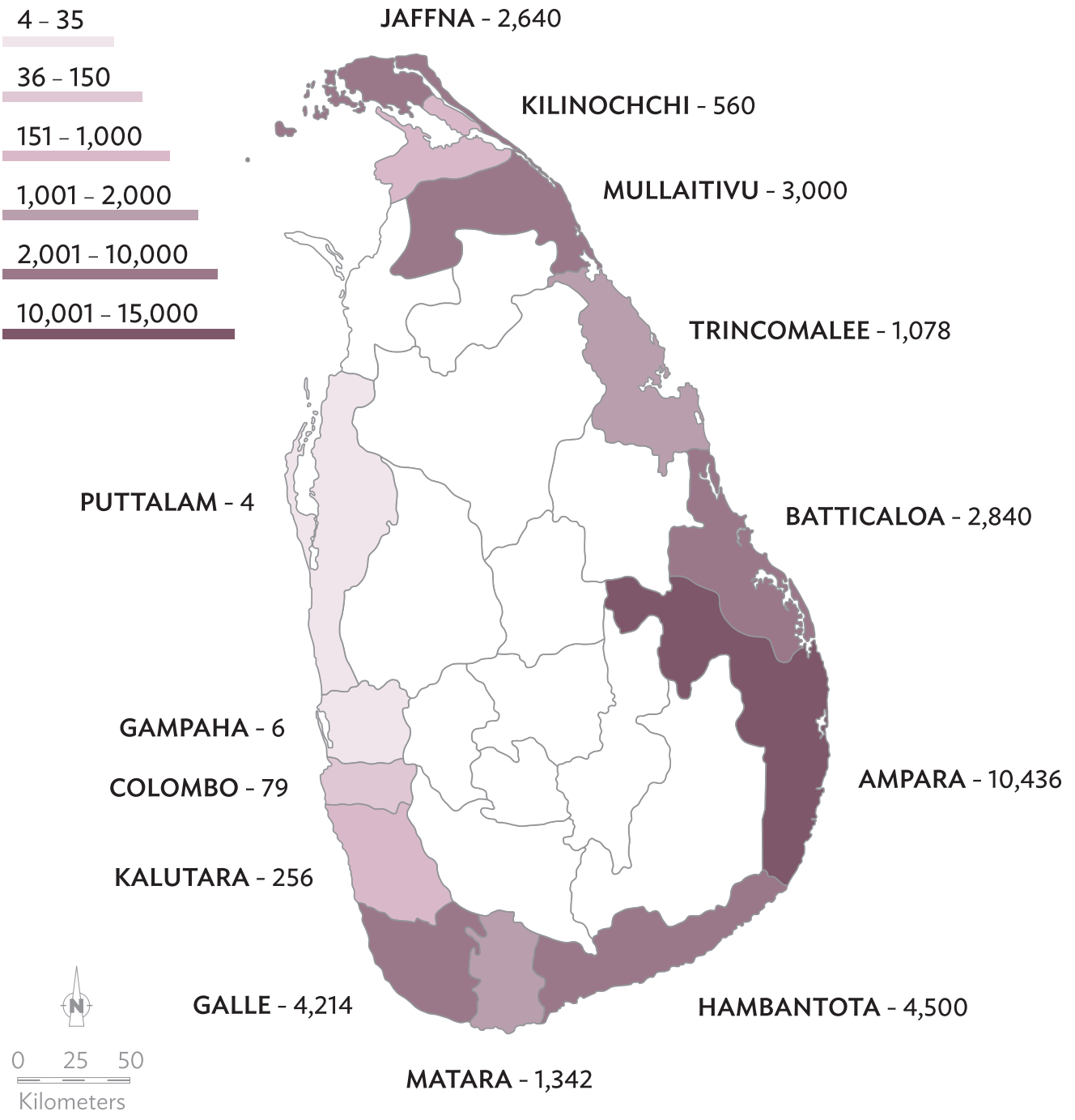

Source: Government of Sri Lanka. 2005. Report on Impact of Tsunami 2004 on Sri Lanka. Department of Census and Statistics. http://www.statistics.gov.lk/tsunami/census/Summarynew.pdf. 
Table 1: Tsunami Damage in Sri Lanka

\begin{tabular}{lrccc}
\hline District & Deaths & $\begin{array}{c}\text { Displaced } \\
\text { Population }\end{array}$ & $\begin{array}{c}\text { Population } \\
\text { that Became } \\
\text { Homeless }\end{array}$ & $\begin{array}{c}\text { Public Infrastructure } \\
\text { Damage } \\
\text { (SLRs million) }\end{array}$ \\
\hline Jaffna & 2,640 & 39,607 & 20,734 & $1,716.4$ \\
Mullaitivu & 3,000 & 22,657 & 22,831 & $2,166.1$ \\
Trincomalee & 1,078 & 81,643 & 36,326 & 3,446 \\
Batticaloa & 2,840 & 61,912 & 70,282 & $3,208.4$ \\
Ampara & 10,436 & 75,172 & 67,707 & $3,959.2$ \\
Hambantota & 4,500 & 17,723 & 8,955 & $1,296.5$ \\
Matara & 1,342 & 13,206 & 28,860 & $2,216.9$ \\
Galle & 4,214 & 128,077 & 53,440 & $4,289.9$ \\
Kalutara & 256 & 27,713 & 24,855 & $1,009.4$ \\
Colombo & 79 & 31,239 & 24,457 & 235.1 \\
Gampaha & 6 & 1,449 & 4,401 & 348.1 \\
\hline Puttalam & 4 & 66 & 228 & 16.9 \\
Kilinochchi & 0 & 1,603 & 1,186 & 232.3 \\
Mannar & 0 & 0 & 0 & 11 \\
\hline
\end{tabular}

Source: Government of Sri Lanka. 2005. Report on Impact of Tsunami 2004 on Sri Lanka. Department of Census and Statistics. http://www.statistics.gov.lk/tsunami/census/Summarynew.pdf.

\section{A. What Can We Learn from the Macroeconomic Data?}

In Figure 3, we compare the growth rate of real per capita GDP in Sri Lanka to the average per capita GDP growth of middle-income countries, South Asia, and the world. Sri Lanka suffered a recession in 2001, but since 2002, including the period following the 2004 tsunami catastrophe, the economic growth of Sri Lanka follows a very similar pattern of growth to the comparison groups. When examining these aggregate figures, it is important to note that Sri Lanka received an unusually large amount of external assistance for rebuilding from 2005 to 2008. As is true elsewhere, the economy of Sri Lanka then suffered a slowdown in 2009 after the global financial crisis hit the entire world economy. Sri Lanka's slowdown, however, was, if anything, milder than elsewhere.

In addition to the global financial crisis, the fighting between army and Liberation Tigers of Tamil Eelam, a well-armed separatist ethnic rebel group, intensified in 2009, and eventually the conflict ended when the army managed to defeat the Liberation Tigers of Tamil Eelam. The double negative shock of the global financial crisis and intensified conflict during 2008-2009 could have severely dented Sri Lanka's growth. In the postcrisis, postconflict period, growth converged to the average observed across other groupings and the global economy. 
Figure 3: Growth of Per Capita Gross Domestic Product at Constant Prices

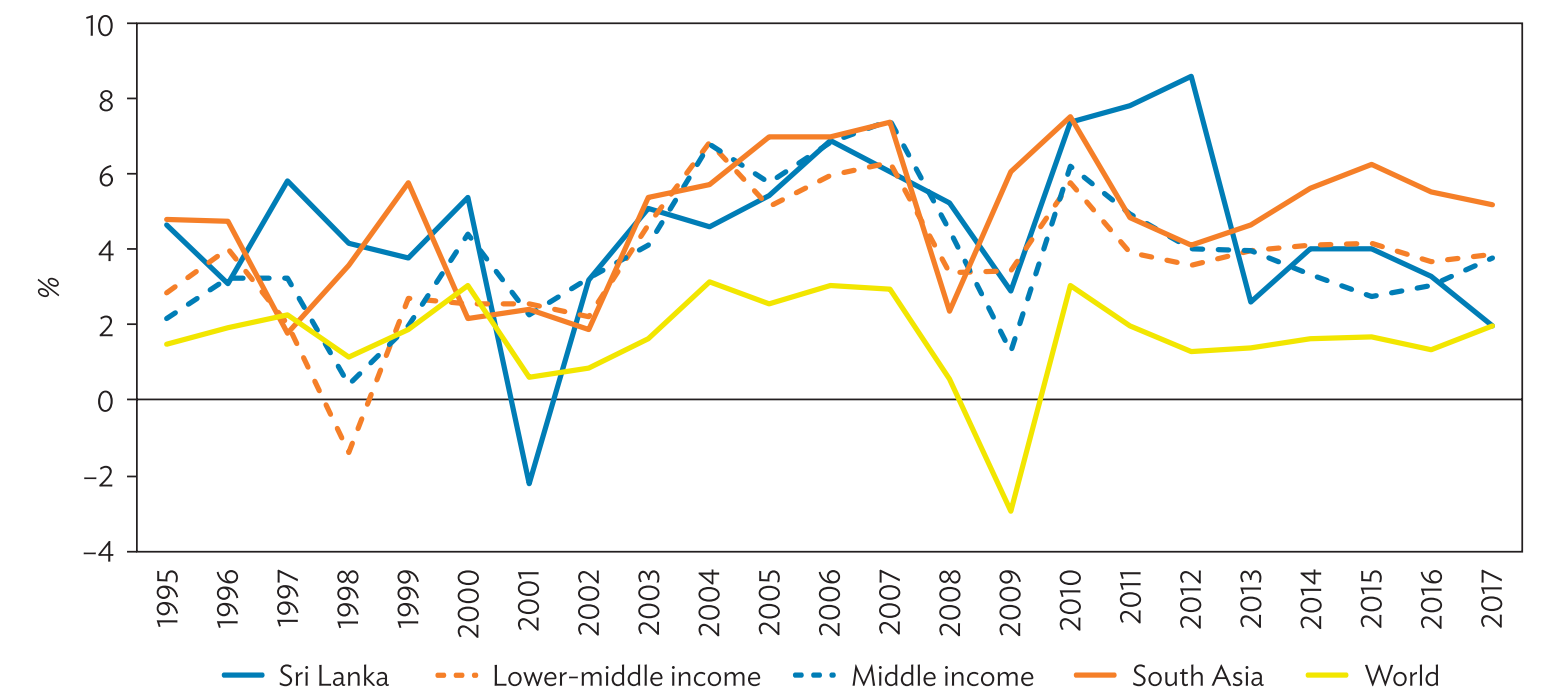

Source: World Bank. 1960-2018. World Development Indicators. Washington, DC. wdi.worldbank.org/ (accessed 12 October 2018).

In Figure 4, we observe that the share of agriculture in the Sri Lankan economy had declined in the early 2000s, but the decline started in 2002, before the tsunami. So, it is difficult to argue there is any evidence that the agriculture sector was disproportionally affected by the tsunami. When the agricultural data is further segmented into its constituents, it is again apparent that the years 20042005 did not bring about substantial change in the agriculture sector. Fishing, which obviously suffered from

Figure 4: Agriculture and Industry Sector Contribution to Gross Domestic Product

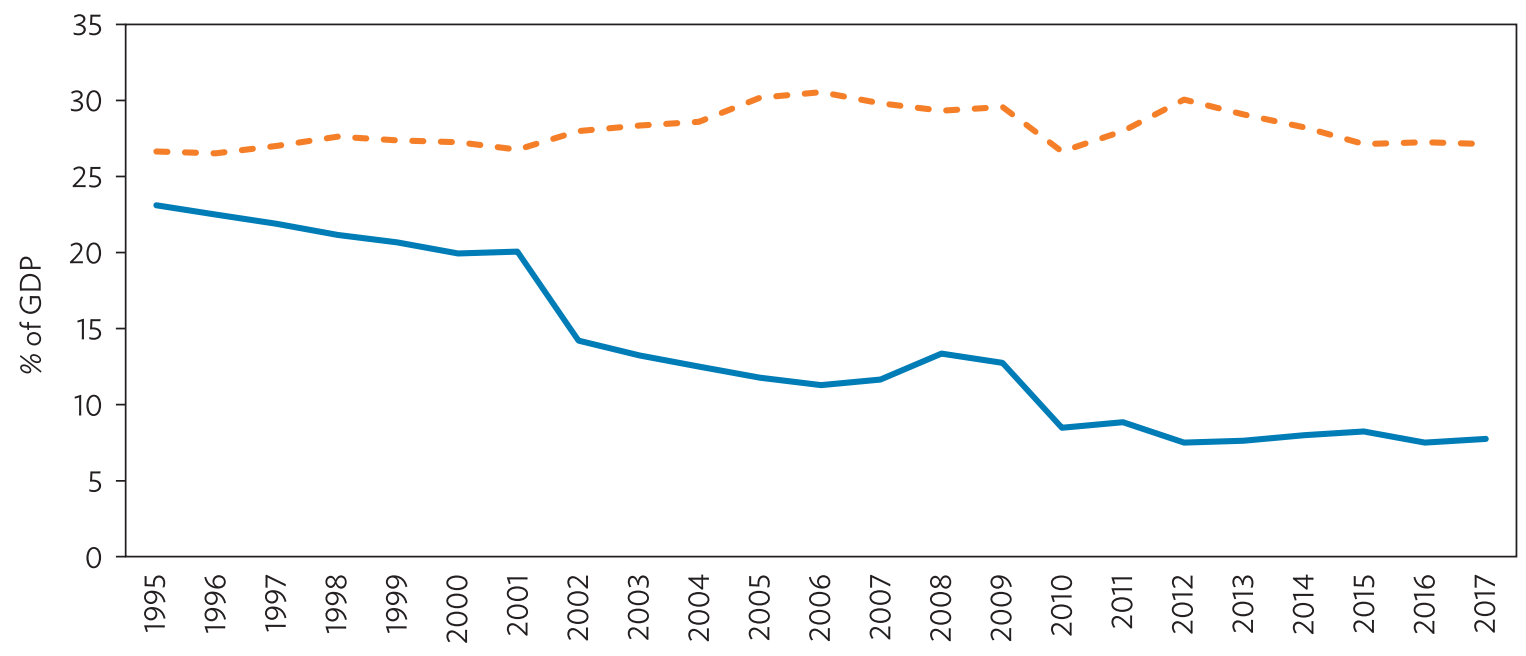

_ Agriculture, forestry, and fishing, value added _ - Industry (including construction), value added 
tsunami damage to fisheries and to the fishing fleet, did experience a short lived and dramatic decline during 2005-2006. However, the long-term consequences are tangible but not that large, and more associated with faster increases in other parts of the economy (Figure 5).

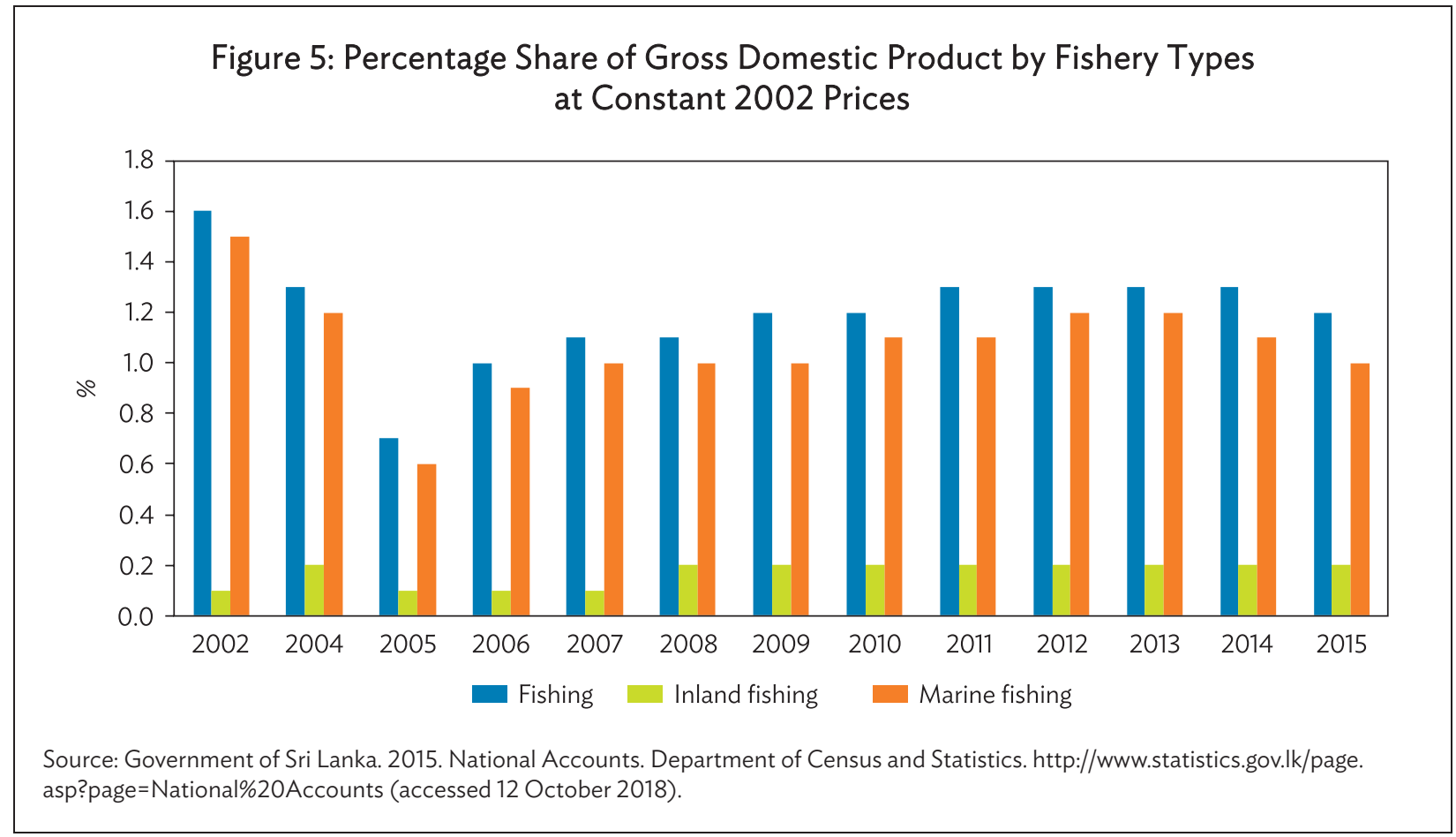

Figure 6 and Table 2 provide more data about the sectoral breakdown of GDP over time in Sri Lanka. The main message from the data is that 2004 does not present any structural break in the sectoral composition of the Sri Lankan economy. In light of that, we should not expect to observe much aggregate long-term adverse impact of the tsunami on the aggregate statistics of the Sri Lankan economy. We do observe an uptick in inflation, most likely due to the increase in demand associated with post-tsunami reconstruction. Eventually, however, inflation did decline about a decade after the tsunami (see Figure 7). 
Figure 6: Percentage Share of Gross Domestic Product by Main Industry Sector Categories at Constant 2002 Prices

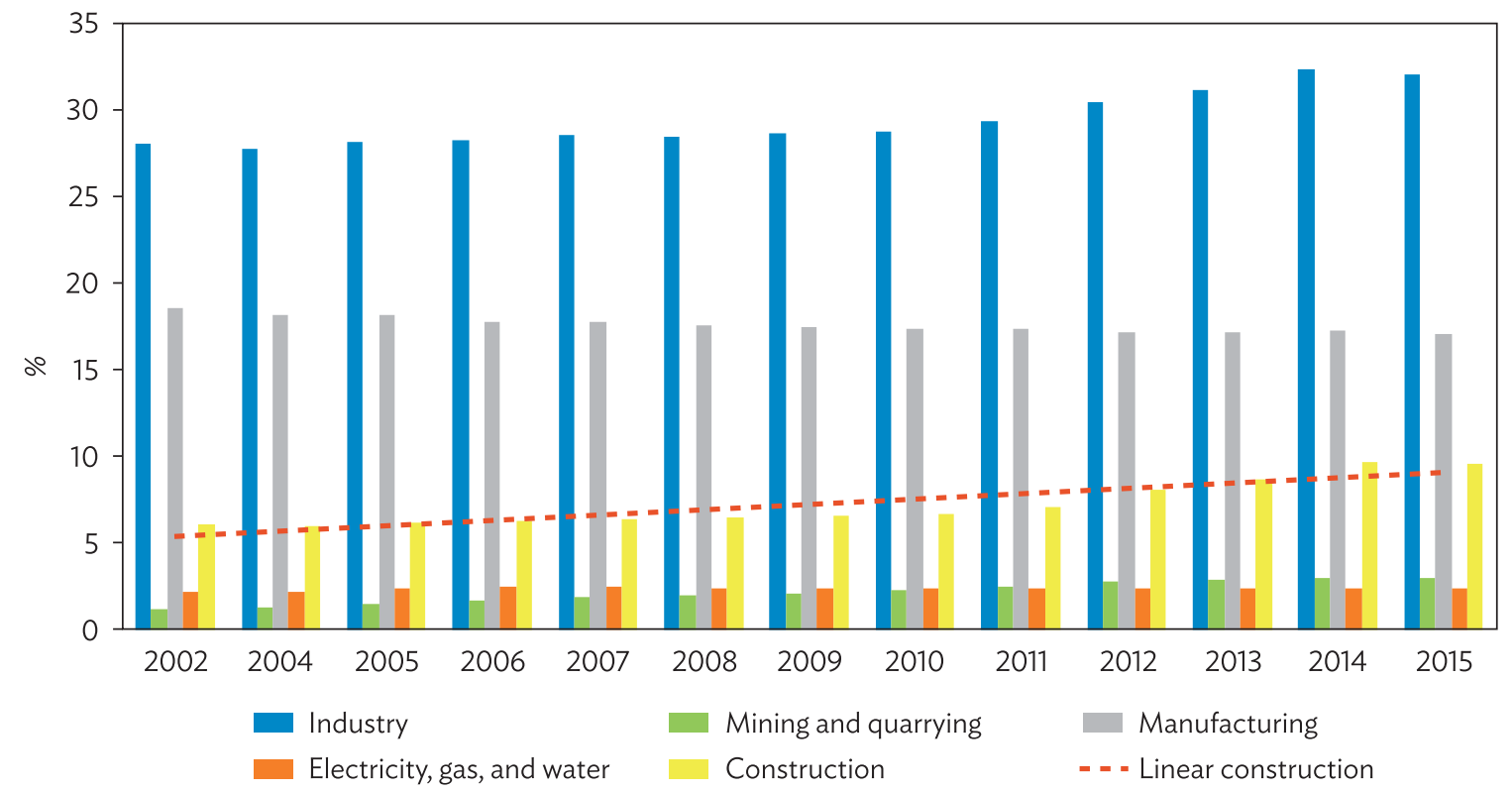

Source: Government of Sri Lanka. 2015. National Accounts. Department of Census and Statistics. http://www.statistics.gov.lk/page. asp?page= National\%20Accounts (accessed 12 October 2018.).

Table 2: Percentage Share of Gross Domestic Product by Main Service Sector Categories

\begin{tabular}{|c|c|c|c|c|c|c|c|c|c|c|c|c|c|}
\hline & 2002 & 2004 & 2005 & 2006 & 2007 & 2008 & 2009 & 2010 & 2011 & 2012 & 2013 & 2014 & 2014 \\
\hline Services & 57.7 & 59.3 & 59.4 & 59.5 & 59.6 & 59.5 & 59.3 & 59.3 & 59.5 & 58.6 & 58.1 & 57.6 & 58.0 \\
\hline Wholesale and retail & 23.8 & 24.7 & 24.7 & 24.6 & 24.5 & 24.2 & 23.3 & 23.2 & 23.6 & 23.0 & 22.7 & 22.8 & 23.3 \\
\hline Hotels and restaurants & 0.2 & 0.6 & 0.5 & 0.5 & 0.4 & 0.4 & 0.4 & 0.5 & 0.6 & 0.7 & 0.8 & 0.8 & 0.8 \\
\hline Transport & 10.6 & 11.5 & 11.9 & 12.4 & 12.8 & 13.1 & 13.5 & 13.9 & 14.3 & 14.3 & 14.6 & 14.6 & 14.5 \\
\hline $\begin{array}{l}\text { Post and } \\
\text { telecommunications }\end{array}$ & 0.6 & 0.8 & 1.1 & 1.2 & 1.4 & 1.6 & 1.7 & 1.8 & 1.9 & 1.9 & 2.0 & 2.0 & 1.9 \\
\hline $\begin{array}{l}\text { Banking, insurance, } \\
\text { and real estate }\end{array}$ & 8.0 & 8.4 & 8.4 & 8.5 & 8.7 & 8.7 & 8.9 & 8.9 & 8.8 & 8.9 & 8.7 & 8.7 & 8.7 \\
\hline Government services & 8.5 & 8.0 & 7.9 & 7.7 & 7.7 & 7.7 & 7.8 & 7.6 & 7.1 & 6.8 & 6.5 & 6.2 & 6.2 \\
\hline Private services & 2.4 & 2.3 & 2.3 & 2.3 & 2.4 & 2.4 & 2.4 & 2.4 & 2.3 & 2.3 & 2.3 & 2.3 & 2.3 \\
\hline
\end{tabular}

Source: Government of Sri Lanka. 2015. National Accounts. Department of Census and Statistics. http://www.statistics.gov.lk/page.asp?page =National\%20Accounts (accessed 12 October 2018).

Puzzlingly, however, the fiscal data do not indicate any significant jump in expenditures in the immediate post-tsunami period (Figure 8 ). This is because much of the funding for reconstruction did not come from general government expenditures, but from foreign aid that was not channeled through the government accounts. 
Figure 7: Inflation and Unemployment

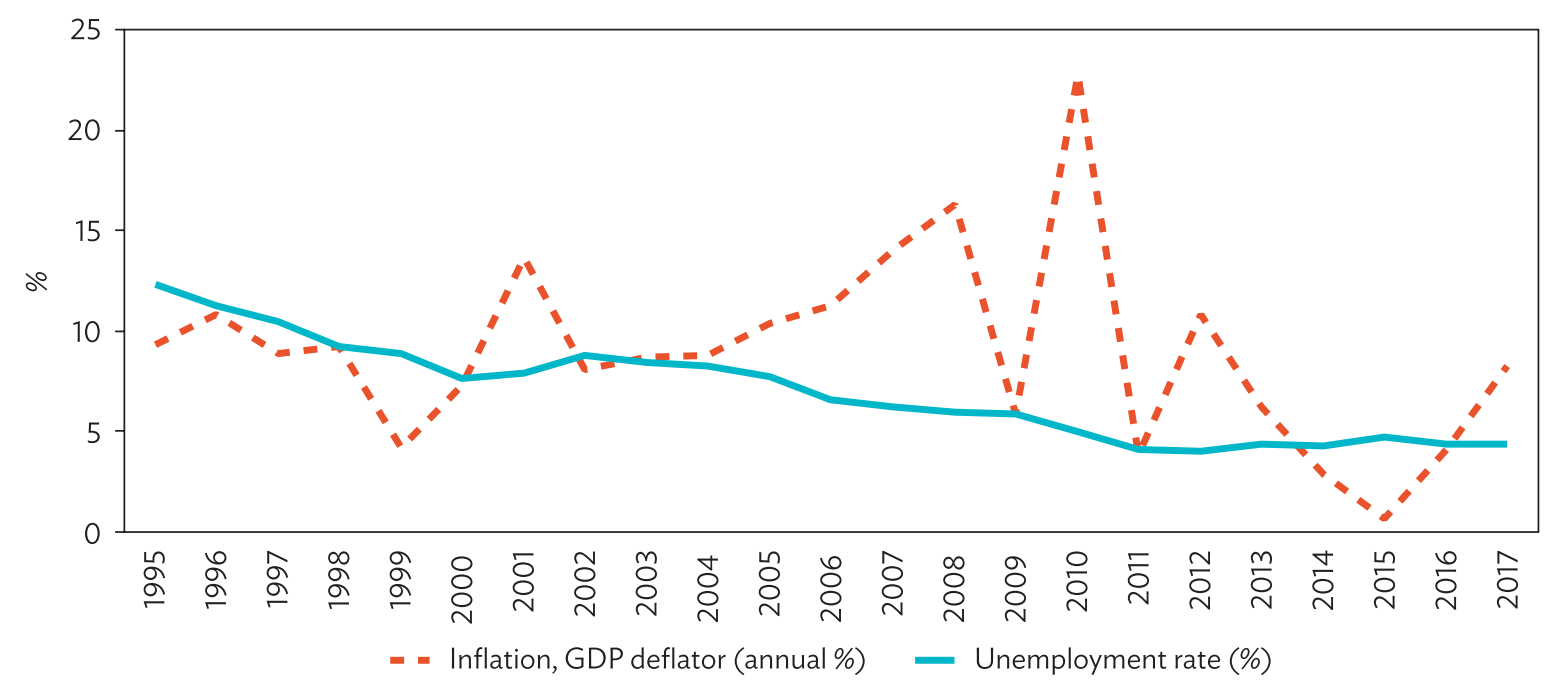

GDP = gross domestic product.

Source: International Monetary Fund. 1948-2018. International Financial Statistics. https://data.imf.org/IFS (accessed 12 October 2018).

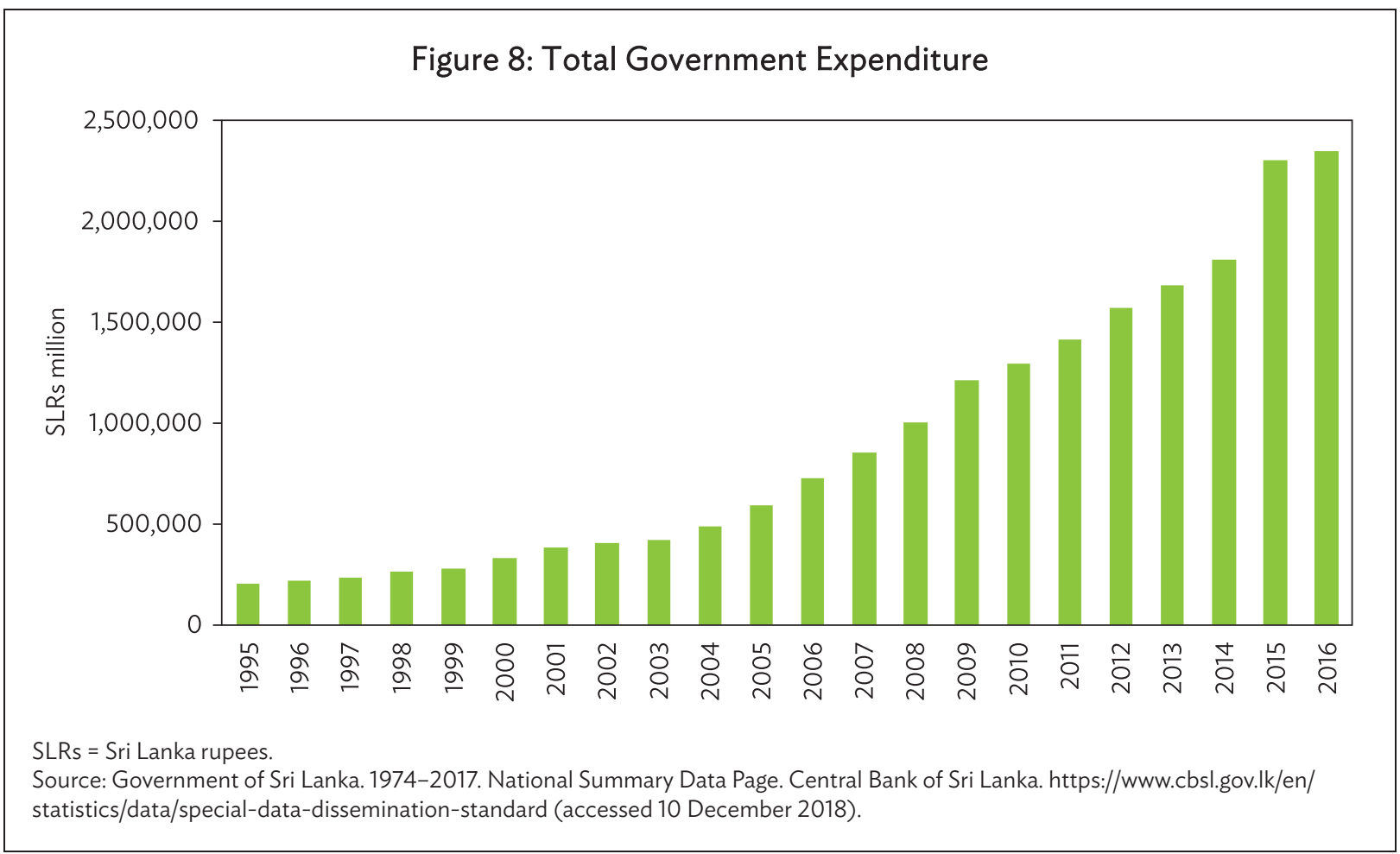

When compared to the averages for advanced and middle-income countries, Sri Lanka has higher current account deficit as a percentage of GDP (Figure 9). After the recession of 2001, the deficit starts to worsen from 2003 until 2008. It improves dramatically from 2008 to 2009 but 
worsens again in 2011. The increase in deficit coincides with the post-tsunami reconstruction and the resolution of the internal conflict. However, it is also affected by the global economic crisis and subsequent recovery, which at first slowed demand for Sri Lanka's exports and later sent import bills soaring, mainly on high oil prices.

In Figure 10, we observe what happened to remittances in the aftermath of the tsunami. As we suggested above, the large inflow of international capital allowed the government to spend heavily on recovery effort without any tangible impact on public finances. Figure 10 shows the large increase in personal remittances to the country in the post-tsunami era. In particular, they peaked in 2005 and 2010, immediately after the tsunami and the end of the conflict, respectively. One can observe an equally dramatic increase in capital inflows in the form of foreign aid. Aid peaked in 2005 and remained elevated in subsequent years (Figure 11).

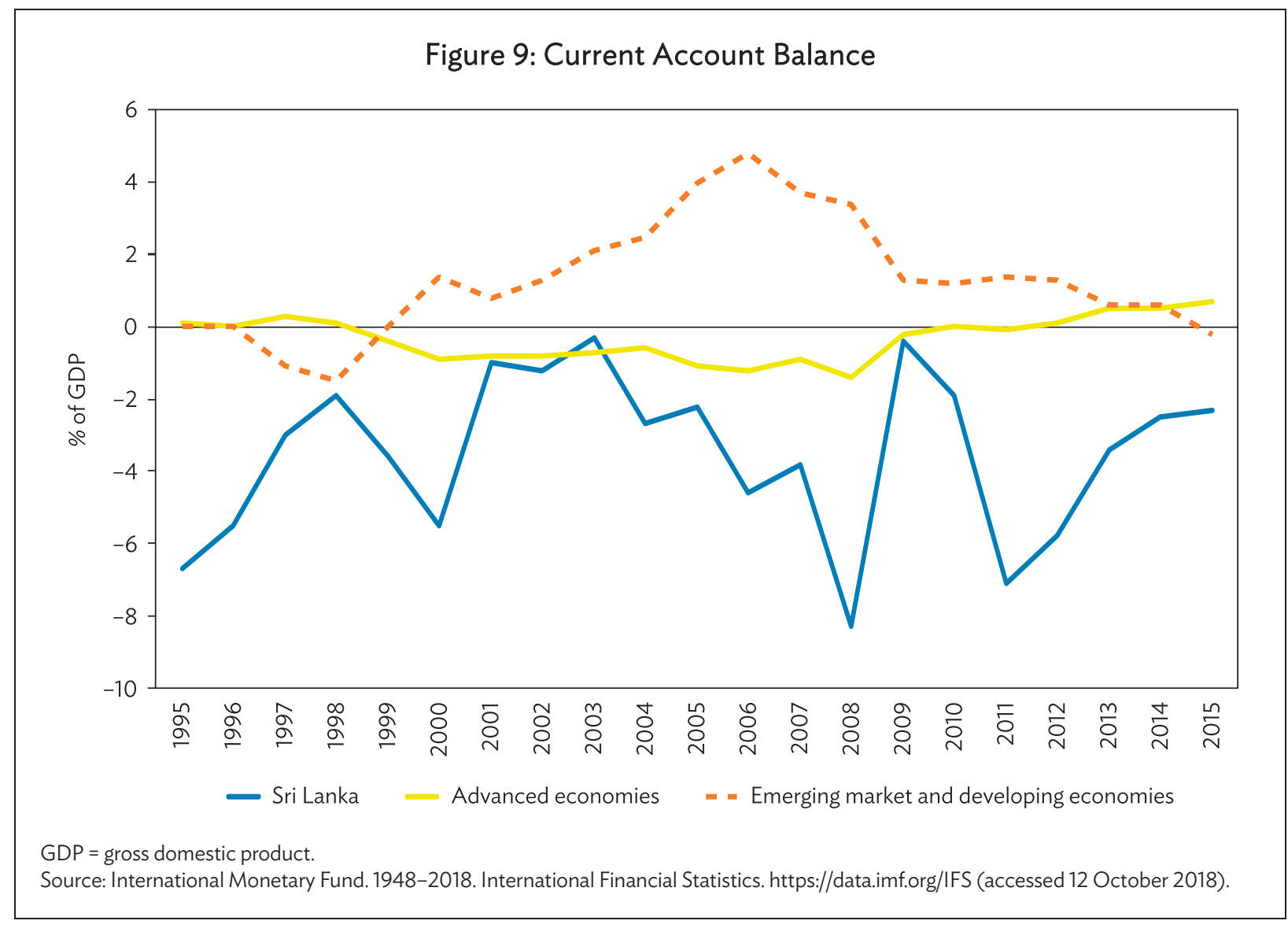


Figure 10: Personal Remittance Growth Rate

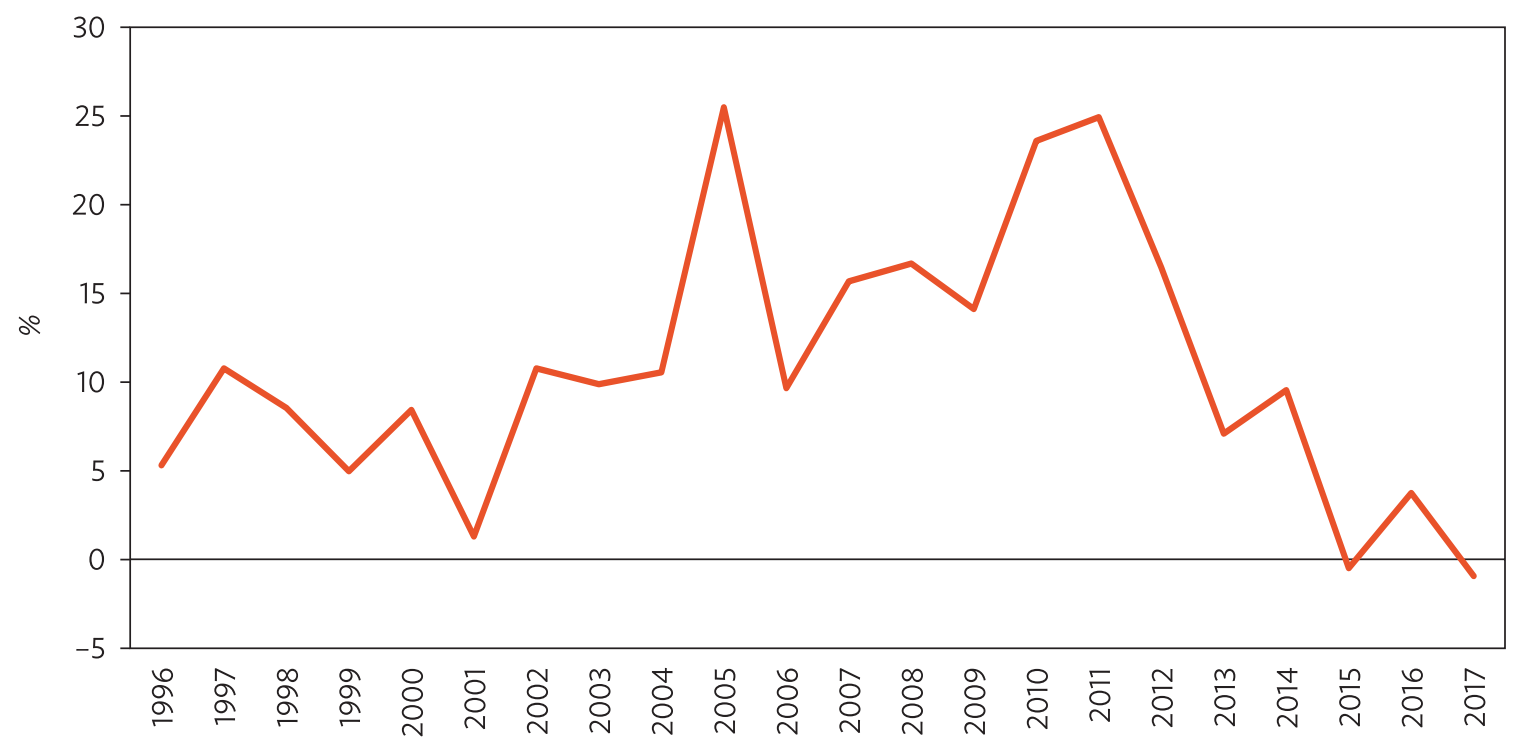

Source: World Bank. 1960-2018. World Development Indicators. Washington, DC. wdi.worldbank.org/ (accessed 12 October 2018).

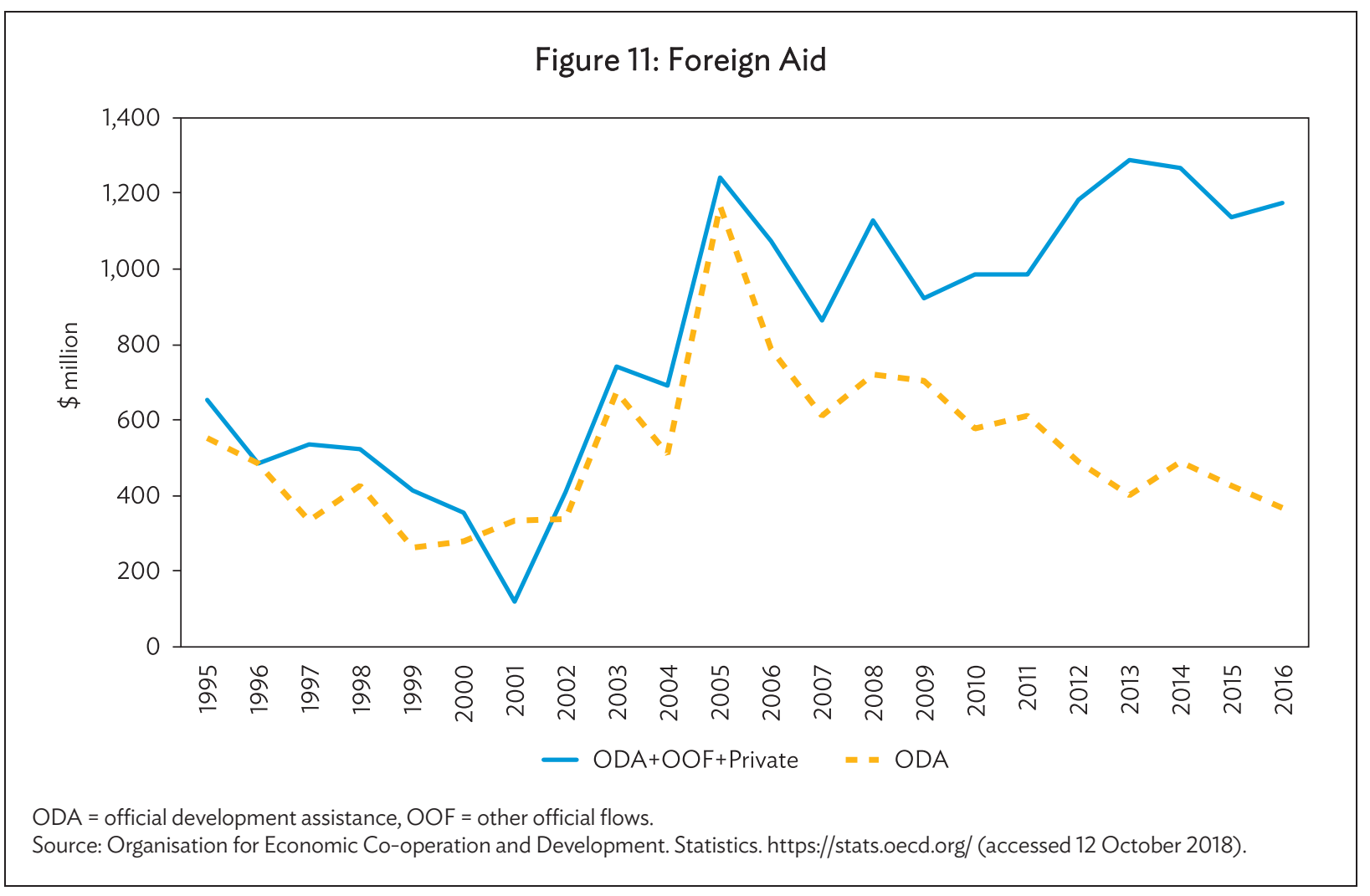




\section{B. What Do the Household Surveys Tell Us?}

In the aftermath of the catastrophe, the Government of Sri Lanka limited reconstruction in a buffer zone along the coast. However, strong opposition from the general public forced the government to abandon this policy. New houses were provided to those who could prove ownership of destroyed houses and through a donor-driven program for those unable to document land ownership. For houses that were completely destroyed, the Government of Sri Lanka provided land and cash grants for rebuilding houses. Sri Lanka drew heavily on foreign financing for its tsunami reconstruction efforts. An extended search for tsunami aid inflow data did not yield reliable data on aid distribution. The Government of Sri Lanka initially estimated that $\$ 2$ billion was needed for reconstruction, including an ambitious BBB reconstruction program (Government of Sri Lanka 2005). Sri Lanka's reconstruction spending approached $\$ 1.4$ billion by the end of 2006 (Jayasuriya and McCawley 2010).

A review of the Reconstruction and Development Agency, the designated authority for tsunami reconstruction coordination in Sri Lanka, reported that $\$ 2.8$ billion in aid was pledged and $\$ 2.3$ billion was committed, but only $\$ 1.2$ billion was disbursed and $\$ 0.8$ billion was expended by midyear 2006. We have not identified any later information sources tabulating these data, and there is no available data that provide any spatial detail. After 2006, the government's standard development program assumed the responsibility for managing tsunami reconstruction.

De Alwis and Noy (2019) examine the household survey data available from the post-tsunami decade, to identify the causal effect of the 2004 tsunami. Household surveys were conducted in 1995, 2002, 2006, 2009, and 2012. The details available in the surveys make them suited to investigate the tsunami's long-term potential for BBB policies when measured by income and consumption at the household level. Measured household consumption expenditures include food, nonfood, durables, as well as insurance and savings. Household income is broken down into paid employment income; net income from agricultural and other work; cash receipts from pension, property rent, dividends and other sources; and both overseas and domestic remittances.

A confounding factor in any analysis of the post-tsunami recovery is the civil conflict that ended in 2009. Cavallo et al. (2013) already postulated that in some cases, disasters lead to institutional and politico-structural changes that can have either adverse or favorable long-term implication for development trajectories. Whether the end of the conflict is at all related to the tsunami is debated-for example, Kikuta (2018). In the other most tsunami-affected area, Aceh province in Indonesia, the end of the civil conflict was directly tied to the tsunami damage and the need to establish access to reconstruction funding. Figure 12 describes the damage data for tsunamiaffected nonconflict districts as a share of population. The findings described below are based on a quantitative analysis of 84,393 complete household records in the years before and after the tsunami; see De Alwis and Noy (2019) for more detail. 
Figure 12: Damage at District Level

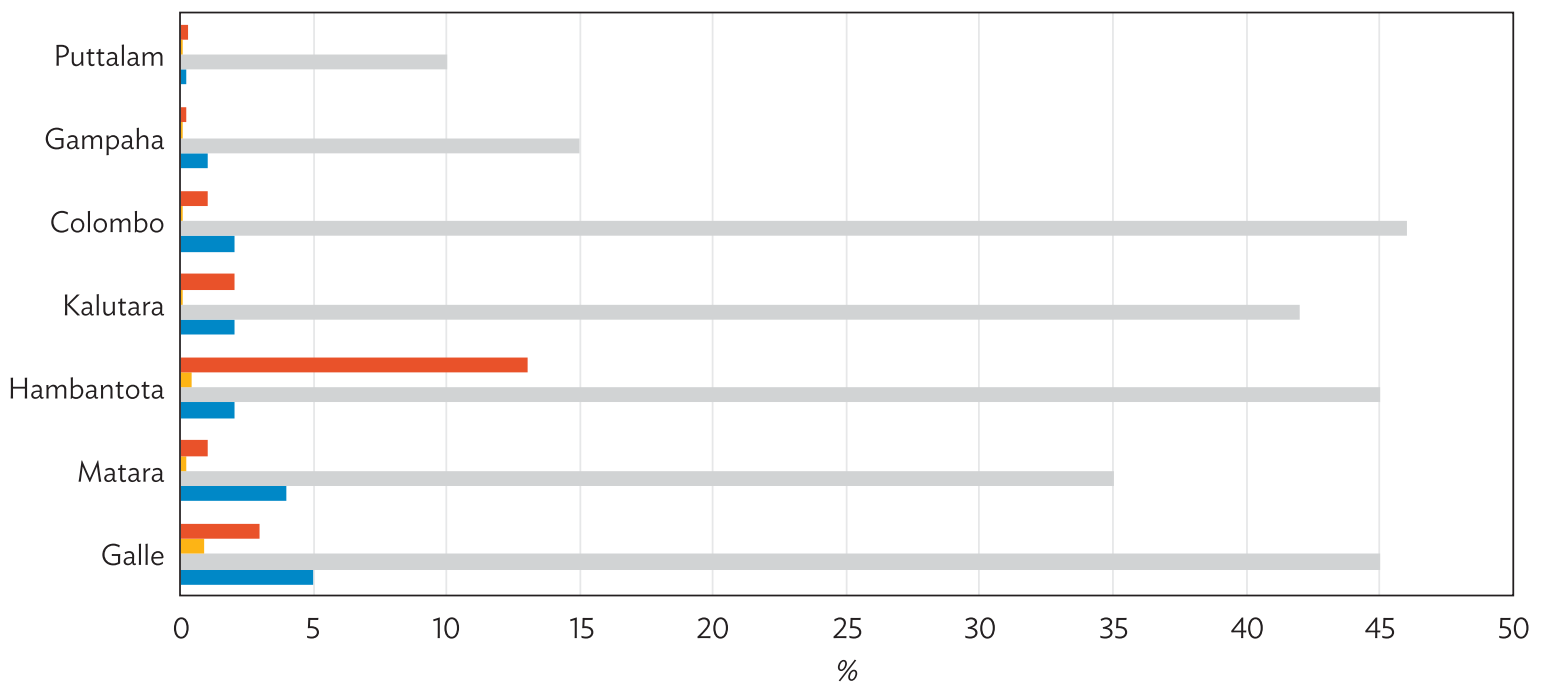

Displaced pop/total population

Total deaths/total population

Population in affected DSDs/total population

Population in damaged houses/total population

DSDs = divisional secretariats in district.

Sources: Government of Sri Lanka. 2015. National Accounts. Department of Census and Statistics. http://www.statistics.gov.lk/page. asp?page=National\%20Accounts (accessed 12 October 2018); Government of Sri Lanka. 2002. Census of Population. Department of Census and Statistics. http://www.statistics.gov.lk/ (accessed 12 October 2018).

Figure 13: Income across Tsunami (Treatment) and Nonaffected (Control) Households

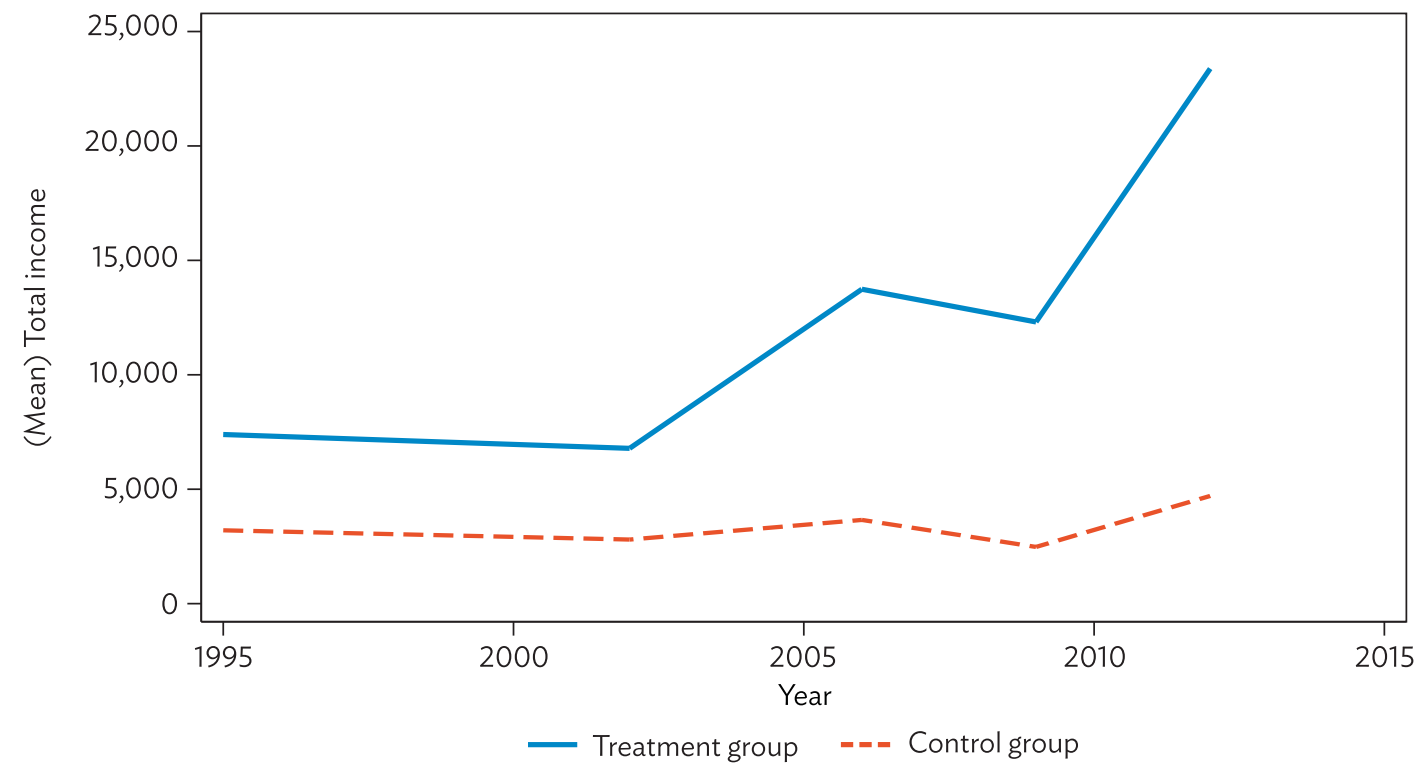

Source: De Alwis, Diana, and Ilan Noy. 2019. "Sri Lankan Households a Decade after the Indian Ocean Tsunami." Review of Development Economics 23 (2): 1000-26. https://onlinelibrary.wiley.com/doi/abs/10.1111/rode.12586. 
Figure 14: Consumption across Tsunami (Treatment) and Nonaffected (Control) Households

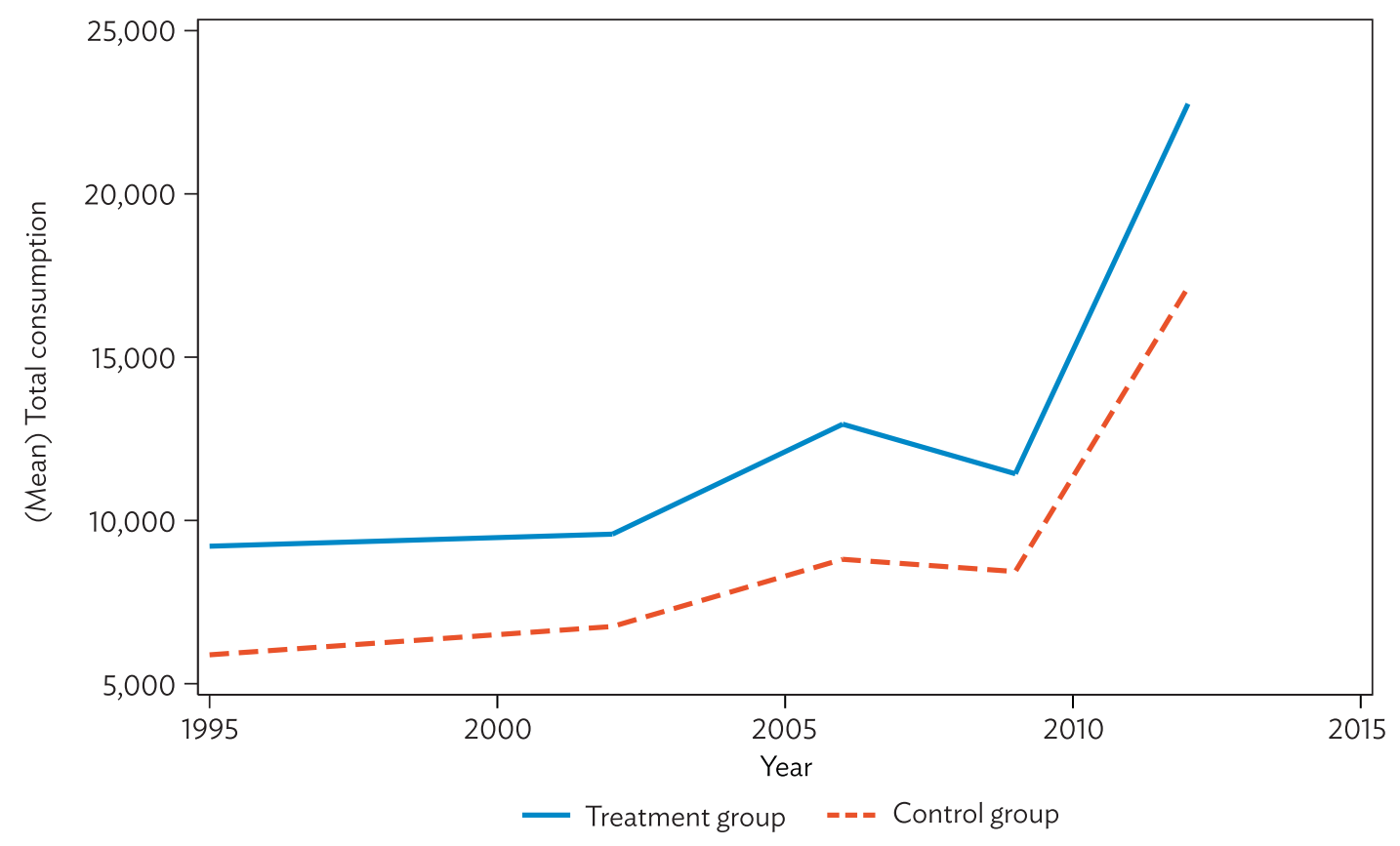

Source: De Alwis, Diana, and Ilan Noy. 2019. "Sri Lankan Households a Decade after the Indian Ocean Tsunami." Review of Development Economics 23 (2): 1000-26. https://onlinelibrary.wiley.com/doi/abs/10.1111/rode.12586.

What were the average impacts of the tsunami over time on the households in the affected districts (Tables 3, 4, and 5)? Overall, De Alwis and Noy (2019) find that incomes increased following the tsunami. That is, incomes increased in districts that were affected by tsunami relative to incomes in districts that were not (Table 3). Notably, while the increase in income is significant in 2006, it is less distinguishable in 2009, a year in which the whole country was experiencing a slowdown because of the global economic crisis, and larger in 2012, which was the peak of the postconflict peace-dividend boom.

Somewhat surprisingly, these increases in income have not fully passed through into increases in consumption expenditures (Table 3). In particular, we observe that while consumption did go up after the tsunami, it increased only by a fifth of the increase in incomes. That is, consumption followed the same dynamics as income, but with much smaller impact. The general perception among agencies conducting household surveys is that consumption expenditure responses are more reliable than income responses. And, in any case, well-being depends more on consumption than income, even if both are correctly measured. Therefore, consumption dynamics are probably more important from a public policy perspective. De Alwis and Noy (2019) find that the identified increase in consumption is roughly split equally between food and nonfood consumption (Table 4).

Generally, the evidence from Sri Lankan household survey data points to a BBB scenario in which incomes and consumption increased. However, the magnitude of the increase for consumption is quite small. 
Table 3: Impact of Tsunami on Household Income and Consumption (SLRs)

\begin{tabular}{lcc}
\hline & Income & Consumption \\
\hline Impact in 2006 & 7,022 & 1,343 \\
Impact in 2009 & $(2372)^{* * *}$ & $(735)^{*}$ \\
& 5,787 & 333 \\
Impact in 2012 & $(3227)^{*}$ & $(500)$ \\
\end{tabular}

SLRs = Sri Lanka rupees.

Notes: Robust standard errors in parenthesis. ${ }^{* *}$ and ${ }^{*}$ denote significance at $1 \%$ and $10 \%$, respectively.

Source: Authors' calculations.

Table 4: Impact of Tsunami on Household Consumption by Type of Consumption (SLRs)

\begin{tabular}{lcc}
\hline & Food Consumption & Nonfood Consumption \\
\hline Impact in 2006 & 597 & 789 \\
& $(284)^{* *}$ & $(545)$ \\
Impact in 2009 & 711 & -318 \\
& $(362)^{*}$ & $(520)$ \\
Impact in 2012 & 1,459 & 1,546 \\
& $(466)^{* * *}$ & $(664)^{* * *}$ \\
\hline
\end{tabular}

SLRs $=$ Sri Lanka rupees.

Notes: Robust standard errors in parenthesis. ${ }^{* *},{ }^{* *}$, and ${ }^{*}$, denote significance at $1 \%, 5 \%$, and $10 \%$, respectively. Source: Authors' calculations.

\section{Table 5: Income Variation Depending on Wealth and Damage Intensity} (SLRs)

\begin{tabular}{lcccc}
\hline & $\begin{array}{c}\text { Exclude } \\
\text { richest districts }\end{array}$ & High intensity & Low intensity & Richest districts \\
\hline Impact in 2006 & $2,427^{* *}$ & $2,298^{* *}$ & $5,459^{* * *}$ & $12,145^{* * *}$ \\
& $(1,042)$ & $(1,048)$ & $(1,800)$ & $(2,966)$ \\
Impact in 2009 & 2,517 & 2,066 & 3,938 & $9,800^{* *}$ \\
& $(1,515)$ & $(1,326)$ & $(2,809)$ & $(4,008)$ \\
Impact in 2012 & $7,579^{* * *}$ & $7,493^{* * *}$ & $11,323^{* * *}$ & $23,552^{* * *}$ \\
& $(1,840)$ & $(1,657)$ & $(3,316)$ & $(5,056)$ \\
\hline
\end{tabular}

SLRs = Sri Lanka rupees.

Notes: Robust standard errors in parentheses. Model estimations controlled for household covariates, that is, sex, age, years of education, ethnicity of household head, household size, as well as district fixed effects and a linear time trend. ${ }^{* *}$ and ${ }^{* *}$ denote significance at $1 \%$ and $5 \%$, respectively.

Source: Authors' calculations. 
Table 6: Consumption Variation Depending on Wealth and Damage Intensity (SLRs)

\begin{tabular}{lcccc}
\hline & $\begin{array}{c}\text { Exclude } \\
\text { Richest Districts }\end{array}$ & High Intensity & Low Intensity & Richest Districts \\
\hline Impact in 2006 & $2,136^{* * *}$ & $3,431^{* * *}$ & 147 & 489 \\
& $(782)$ & $(796)$ & $(617)$ & $(630)$ \\
Impact in 2009 & 644 & 1,520 & -127 & -63 \\
& $(788)$ & $(1,024)$ & $(607)$ & $(785)$ \\
Impact in 2012 & $2,143^{* *}$ & 2,047 & $2,796^{* * *}$ & $3,765^{* * *}$ \\
& $(1,008)$ & $(1,312)$ & $(749)$ & $(861)$ \\
\hline
\end{tabular}

SLRs $=$ Sri Lanka rupees.

Notes: Robust standard errors in parentheses. Model estimations controlled for household covariates, that is, sex, age, years of education, ethnicity of household head, and household size, as well as district fixed effects and a linear time trend. ${ }^{* * *}$ and ${ }^{* *}$ denote significance at $1 \%$ and $5 \%$, respectively.

Source: Authors' calculations.

This study estimated the tsunami's impact for treated subsamples of tsunami-affected districts: (i) subsample excluding the richest districts, (ii) districts that suffered high-intensity damage, (iii) districts that suffered low-intensity damage, and (iv) districts with the highest incomes. Table 6 shows that the incomes of districts with low-intensity damage expanded consistently faster than the incomes of districts with high-intensity damage. In addition, the incomes of the richest districts grew much more than the incomes of the treatment subsample without those districts. These findings suggest that income gains are inversely proportional to damage intensity and biased toward the richest districts.

The equivalent results for consumption in Table 5 show sustained consumption gains for the subsample that exclude richer districts. In contrast, such gains only materialize in the first postdisaster year for intensely affected districts. In contrast to income gains, consumption gains appear only in the long term for the least damaged or richest districts. These findings suggest limits to the transformation of income gains to consumption gains among these two groups. The researchers provide two possible explanations for the discrepancy between the income and consumption boost: (i) translation of income to assets, which were not evaluated or counted as consumption due to lack of household wealth data; and (ii) positive consumption spillover boosts to unaffected districts (thereby lowering the estimated impact).

Another study (De Alwis 2018) evaluated the effects of the recovery on Sri Lanka's income distribution using quantile incomes and other inequality measures. This study found that the income of affected households of all income groups recovered, with low-income households enjoying a proportionately larger increase in income, compared to higher-income households. A similar pattern held for consumption. Overall, that study did not find any long-term evidence of greater inequality associated with post-tsunami recovery in Sri Lanka.

\section{What Can We Conclude about Build Back Better in Sri Lanka after 2004?}

As elaborated on in section V.A, aggregate data suggest that Sri Lanka experienced a full and rapid macroeconomic recovery. This is not unusual for macroeconomic dynamics after disaster events. 
Indeed, relatively rapid recovery of aggregate economic activity was described by Adam Smith and John Stewart Mill some centuries ago.

The more interesting dynamics and the more intriguing information can be gleaned from household data based on the government's household income and expenditure surveys. Generally, they point to increased incomes and consumption after the tsunami. However, the increase in consumption is marginal and then only in the long term for least damaged or richest districts.

Even investigations of household data far from complete the puzzle, since measures of income in these surveys do not include the receipts of in-kind tsunami assistance. Especially important in this context is housing, which accounted for a large part of the assistance that households received (Hettige and Haigh 2016). The expenditure measures did not capture housing either, since they did not include information on the purchase of durable assets and property. As such, these indicators only provide a limited view of what happened to households in the post-tsunami period. The quality of housing is yet another complicating factor. Hettige and Haigh (2016) conduct qualitative field work in 10 affected communities in Ampara, Batticaloa, and Galle districts a decade after the tsunami. They find that while residential recovery is complete-that is, practically everyone is in some permanent accommodation - there are many problems with the quality of housing under the new arrangements.

\section{THE 2008 WENCHUAN EARTHQUAKE}

On 12 May 2008, a massive earthquake measuring 8.0 on the Richter scale struck the southwest area of the PRC (ADB 2008). The epicenter was in Wenchuan county, 92 kilometers northwest of the Sichuan capital of Chengdu. There were 10 disaster-affected provinces and cities (in order from the most damaged: Sichuan, Gansu, Shaanxi, Chongqing, Yunnan, Hubei, Guizhou, Henan, Shanxi, Hunan). Sichuan, Gansu, and Shaanxi were the hardest-hit provinces, with Sichuan suffering by far the most damage, including $99 \%$ of mortality and morbidity (Tables 7 and 8 ).

Table 7: Affected Areas and Damage

\begin{tabular}{|c|c|c|c|c|c|c|}
\hline Province & $\begin{array}{l}\text { Number } \\
\text { of Worst } \\
\text { Affected } \\
\text { Counties }\end{array}$ & $\begin{array}{c}\text { Number } \\
\text { of Seriously } \\
\text { Affected } \\
\text { Counties }\end{array}$ & $\begin{array}{l}\text { Number } \\
\text { of Slightly } \\
\text { Affected } \\
\text { Counties }\end{array}$ & Deaths & $\begin{array}{l}\text { Number } \\
\text { of Missing } \\
\text { People }\end{array}$ & $\begin{array}{l}\text { Number } \\
\text { of Injured } \\
\text { People }\end{array}$ \\
\hline Sichuan & 10 & 29 & 100 & 68,708 & 17,923 & 360,796 \\
\hline Gansu & & 8 & 32 & 370 & & 10,165 \\
\hline Shaanxi & & 4 & 36 & 125 & & 2970 \\
\hline Chongqing & & & 10 & 19 & & 637 \\
\hline Yunnan & & & 3 & 1 & & 51 \\
\hline Total & 10 & 41 & 186 & 69,227 & 17,923 & 374,643 \\
\hline
\end{tabular}

Source: Asian Development Bank. 2008. Technical Assistance Project (TA-7081-PRC): People's Republic of China: Providing Emergency Response to Wenchuan Earthquake. Manila. 
Table 8: Sum of Direct Damage and Losses

(CNY million)

\begin{tabular}{lrrrr}
\hline Province & Total & Sichuan & Gansu & Shaanxi \\
\hline Social sector (housing and property) & 465,275 & 418,830 & 34,498 & 11,947 \\
Infrastructure & 188,134 & 168,794 & 11,765 & 7,577 \\
Productive sector (agriculture, industry, and services) & 144,338 & 139,466 & 2,563 & 2,309 \\
Cross cutting (land, minerals, cultural heritage, etc.) & 47,387 & 44,680 & 1,709 & 998 \\
Total & 845,136 & 771,770 & 50,535 & 22,830 \\
\hline
\end{tabular}

$\mathrm{CNY}=$ yuan.

Source: Asian Development Bank. 2008. Technical Assistance Project (TA-7081-PRC): People’s Republic of China: Providing Emergency Response to Wenchuan Earthquake. Manila.

This high-intensity earthquake triggered a large number of aftershocks. The most severely affected areas in Sichuan were mountainous, mostly at 3,000 meters above sea level. The disasteraffected region includes impoverished regions and less developed ethnic minority regions, as well as more economically developed urban regions, like the cities of Chengdu, Deyang, and Mianyang. The earthquake badly damaged or destroyed houses, property, rail transport, power supply, water and sanitation facilities, hospitals, clinics and lifeline facilities, roads, buildings, and communication networks throughout the affected region. The earthquake and aftershocks entailed secondary disasters such as the creation of many large barrier lakes, which temporarily posed a significant threat to millions of people downstream in Mianyang. The total reconstruction cost was estimated at 1 trillion yuan (CNY), nearly equal to the GDP of Sichuan province or 3.9\% of the PRC's national GDP in 2007.' The vast majority of households and businesses were not covered by insurance, as is typical for disasters in lower-income countries (Wu, Li, and Xie 2012).

In 2009, in response to the global economic crisis the government passed a massive CNY4 trillion stimulus package, of which 25\% went to earthquake reconstruction. In addition, richer provinces were paired with disaster-affected counties and were required to put aside $1 \%$ of provincial government revenues to assist in the reconstruction work in partner counties. Those funds were very large relative to the ordinary budgets of those counties. In addition, by the end of September 2009, CNY79.7 billion in social contributions had been mobilized from individuals and nongovernment organizations inside and outside of the PRC.

\section{A. What Can We Learn from the Macroeconomic Provincial Data?}

We present several data series for Sichuan province. The regional economic indicators indicate a fast aggregate recovery from the earthquake. It appears that reconstruction had a stimulus effect on the region's economy that generated benefits for a few years and then waned. As Figures 15 and 16 show, per capita GDP did not show any noticeable change during and after the 2008 earthquake except a marginal reduction of growth in 2008, the year of the earthquake (and also of the global financial crisis).

CNY1 $=\$ 0.15$ (as of 11 April 2019). 
A major driver of the quick macroeconomic rebound was the construction sector, which increased rapidly since 2008 (Figures 17, 18, and 19). The construction industry remains strong years after the reconstruction boom of the immediate postearthquake period.
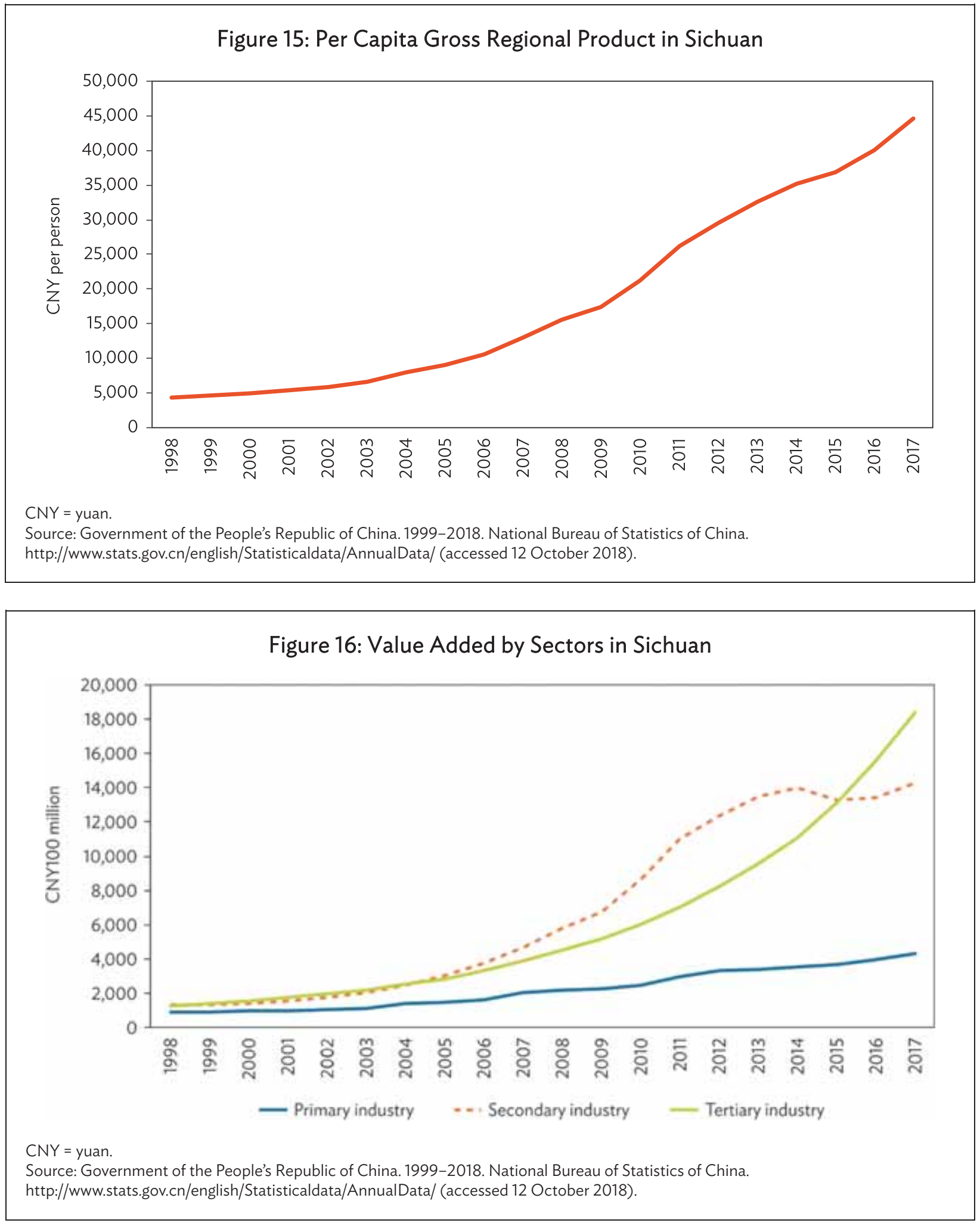

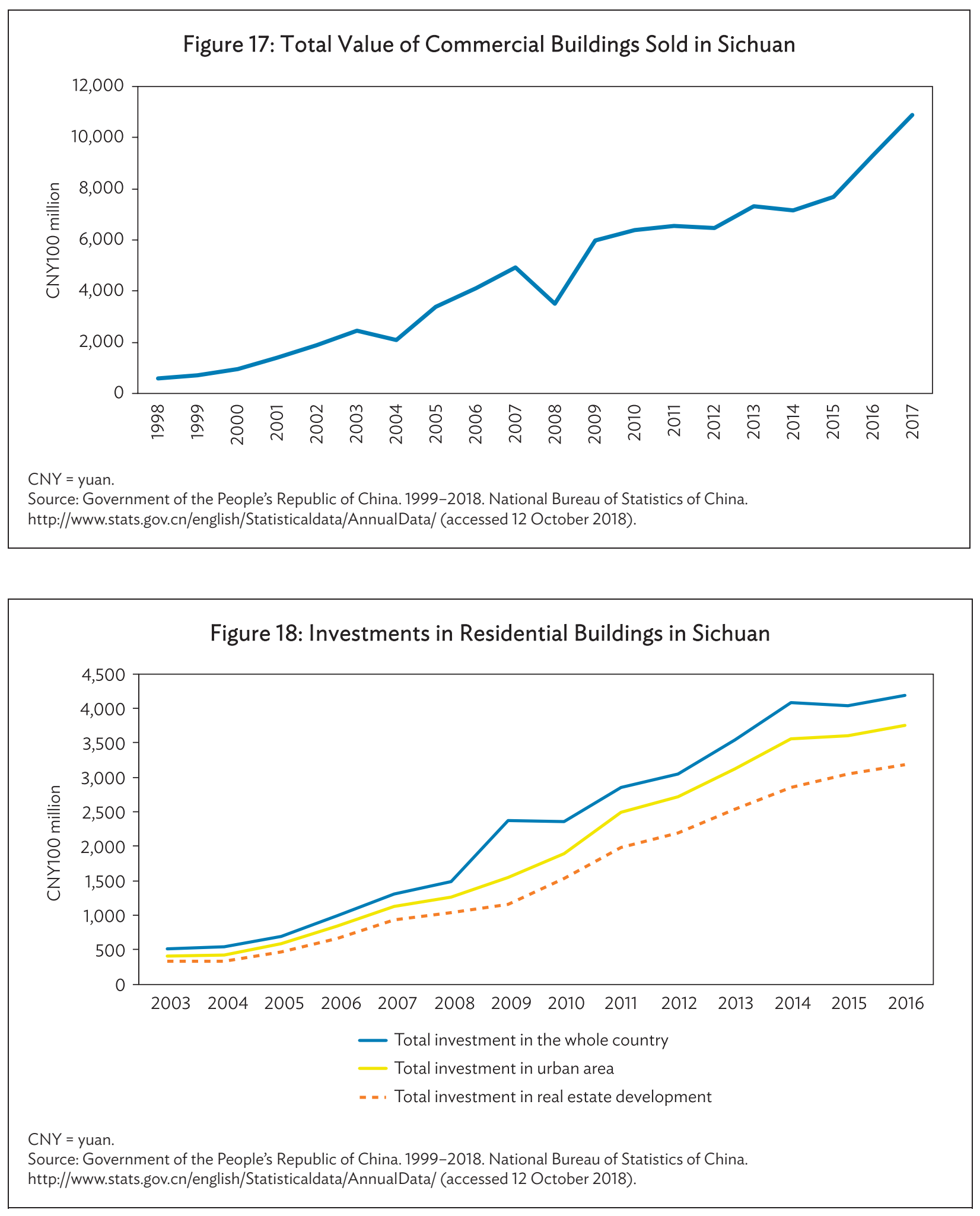


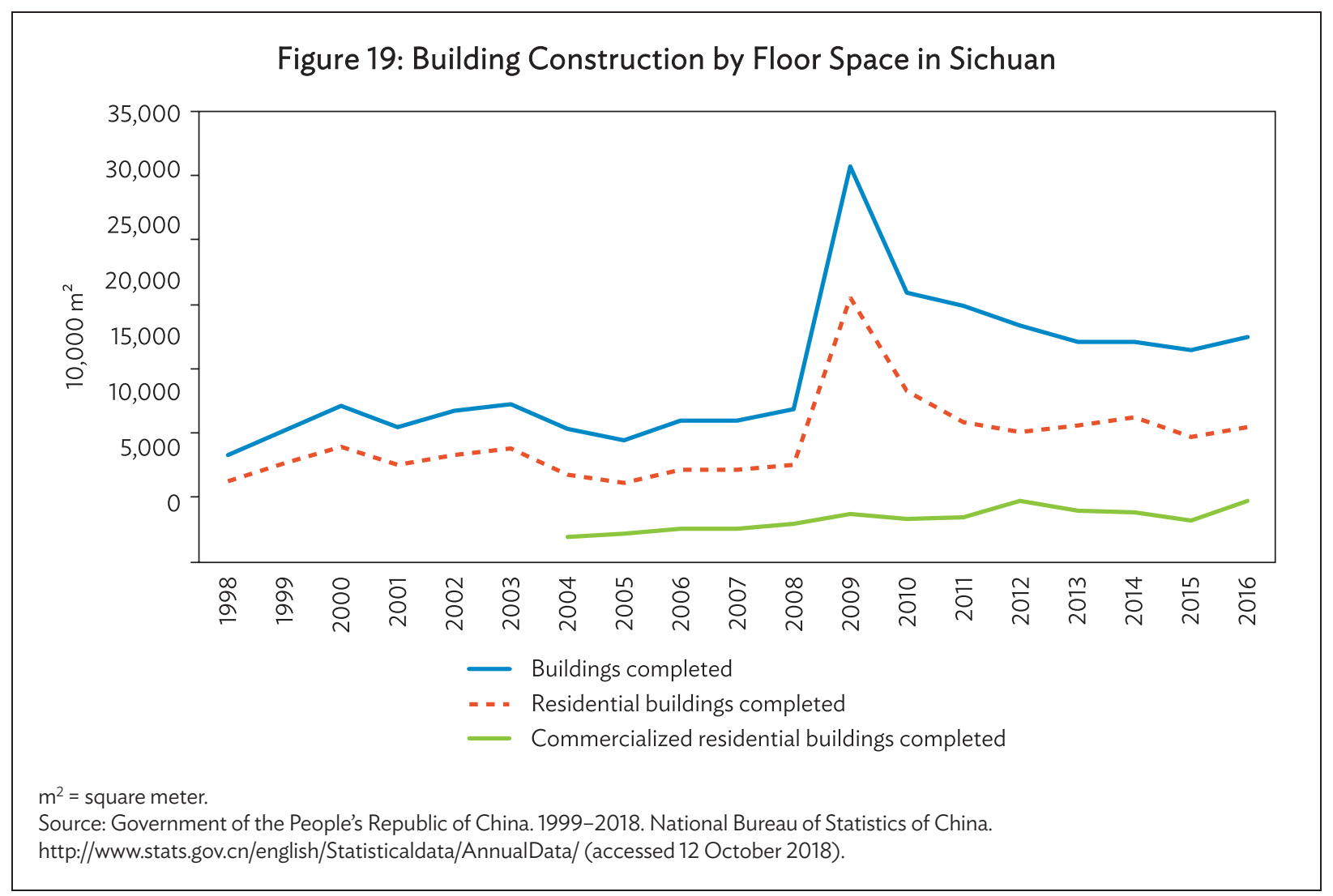

Figure 20 shows the inflation rate of Sichuan province. Somewhat counterintuitively, there is no observable impact on inflation in any of the sectors for which we have inflation (consumer price index) data. Trends in government expenditures (Figure 21) indicate that the Sichuan provincial government is consistently spending more, but money earmarked for reconstruction and recovery was only available in the immediate postearthquake period (2008-2011). Another sign of a strong recovery is the rebound in provincial population since 2010 (Figure 22). 

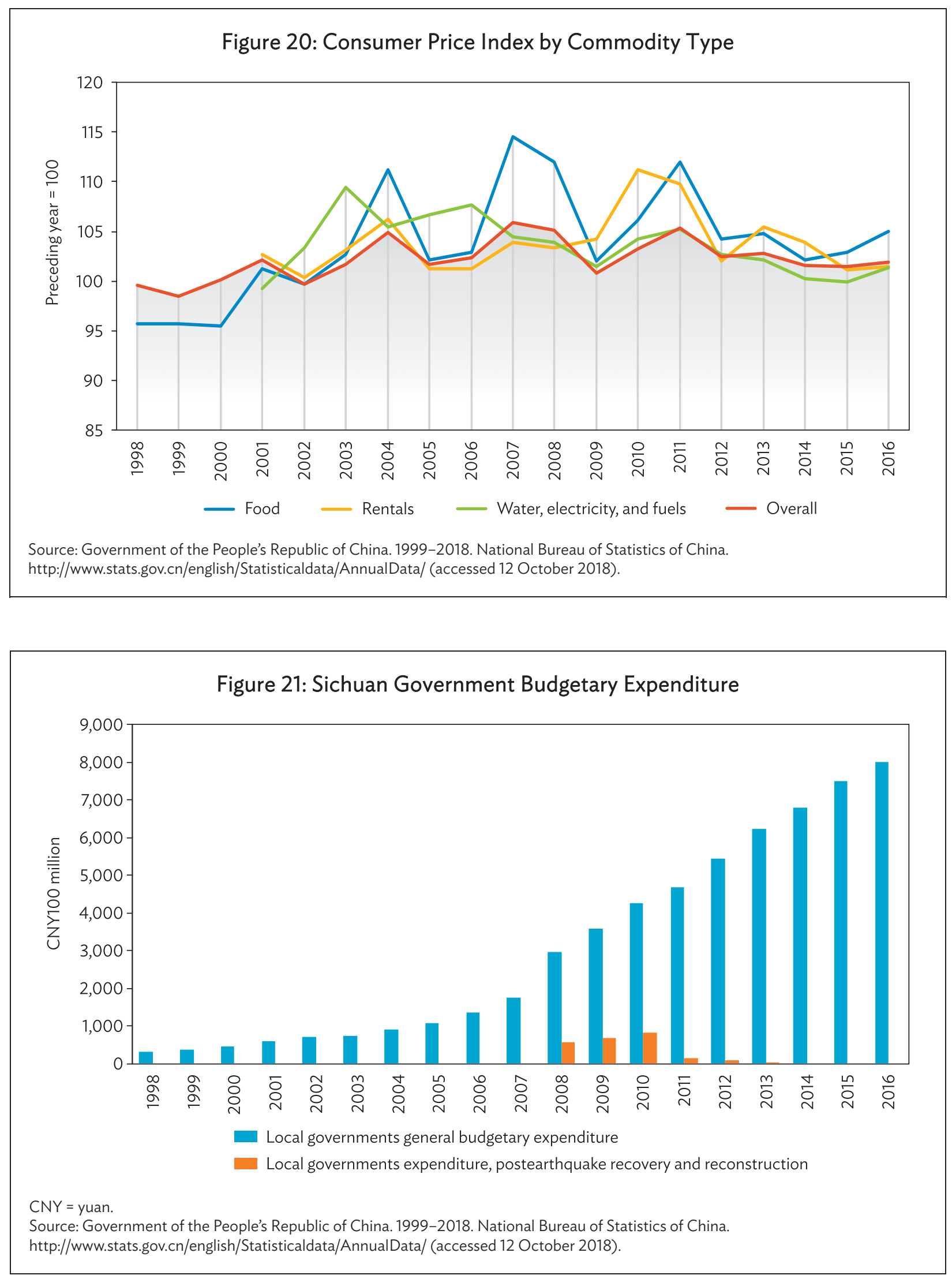
Figure 22: Resident Population in Sichuan

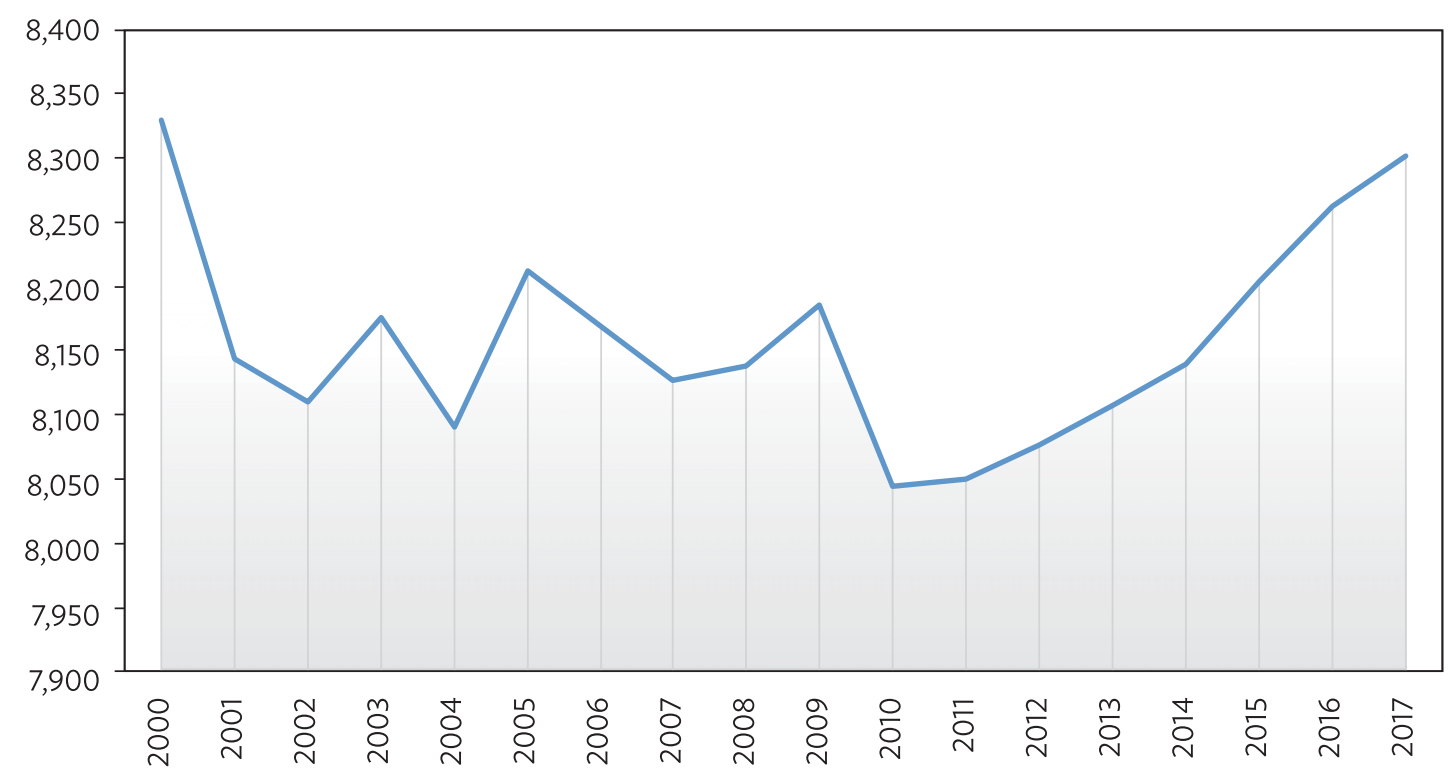

Note: At year-end, 10,000 people.

Source: Government of the People's Republic of China. 1999-2018. National Bureau of Statistics of China. http://www.stats.gov.cn/english/Statisticaldata/AnnualData/ (accessed 12 October 2018).

\section{B. What Do the Household Surveys Tell Us?}

In their analysis, Park and Wang (2017) use data from a unique survey conducted 10 months after the earthquake. The survey sampled 3,000 rural households living in 100 poor villages in 10 counties in disaster-affected areas. They find that asset and income losses for surveyed households were substantial, especially in the hardest-hit areas. They describe "an overwhelming government response to the disaster." Subsidies provided to households in 2008 were so large that mean income per capita was $17.5 \%$ higher in 2008 than in 2007 , and the poverty rate actually plummeted from $34 \%$ to $19 \%$.

The survey asked retrospective questions about the household's economic conditions before and after the earthquake, including detailed information on income from various sources. The survey also asked direct questions about the value of damage inflicted by the earthquake. The extent of government support for victims of the Wenchuan earthquake was not only impressive but unprecedented in scope and scale (Park and Wang 2017). Indeed, households on average were better off during the year of the earthquake.

Luo and Kinugasa (2018) use aggregate provincial data for the period 1995-2015 for their analysis. Utilizing a synthetic control approach, they assess the disaster's impact on household saving. Maybe not surprisingly, they find that the savings rate of rural households declined drastically following the earthquake but recovered quickly in the subsequent year. It appears that while there was a significant short-term effect on household saving, the event did not influence people's long-term behavior with regards to savings. This may be partly due to the generous disaster relief that the victims received. 


\section{POLICY CONCLUSIONS ABOUT BUILD BACK BETTER}

Kennedy et al. (2008) observed that "building back safer" might be a preferable tagline to "building back better." "Better" has multiple interpretations, many of which can cause further problems and the accumulation of risk, whereas "safer" provides a clearer goal for anchoring postdisaster settlement and shelter. Following that logic, the World Bank has suggested three separate BBB components: stronger, faster, and more inclusive (Hallegatte, Rentschler, and Walsh 2018). Here, we further develop these criteria to propose four components: safe, fast, fair, and with future potential. We describe each of these below.

\section{A. Build Back Safe}

Reducing the likelihood of mortality and morbidity in future events is undoubtedly an uncontroversial goal of any recovery and reconstruction in the aftermath of an event. Ceteris Paribus, it is likely to always be one of the more important goals guiding government policy. It seems indisputable that safety should be prioritized, especially because unsafe or less safe reconstruction affects individual households in the disaster zone for a very long time. Hallegatte, Rentschler, and Walsh (2018), use the term "stronger" instead of "safer." This implies reconstructing facilities-that is, housing, public buildings, and transportation infrastructure-so that they are stronger and better able to withstand an extreme hazard event. However, safety can also be achieved by softer defenses such as the wellknown example of mangrove forests protecting against sea surges, or even the soft defense of retreating from an exposed location (Hino, Field, and Mach 2017). It is possible to build safer communities by other policies that do not involve "strong" hard defenses. For example, strengthening social ties within communities can make them safer, as can establishing more efficient ways to evacuate when an early warning system alarm goes off-for example, by widening roads.

\section{B. Build Back Fast}

Rebuilding faster is another fairly obvious and uncontroversial goal for public policy. The problem, of course, is that the quest for speed is often in conflict with some of the other aims of BBB. In both Sri Lanka and Sichuan, the respective governments made a concerted effort to speed up the recovery process. In both cases, one notable uniqueness of the recovery process was the exceptionally ample resources to fund reconstruction. In Sri Lanka, the government received substantial financial support from the international community. The determinants of emergency financial support in the international context are established. These determinants include need, but also include other aspects such as geostrategic interests of donor countries and multilaterals. There were probably two additional reasons why Sri Lanka was relatively well supported after this catastrophe. First, Sri Lanka was more accessible than Aceh, the most heavily affected region in the island of Sumatra, Indonesia. Second, the country was a familiar destination for tourists from some of the main donor countries (again, unlike Aceh).

Indeed, compared to other events-for example, the 2008 tropical cyclone Nargis in Myanmar, or even reconstruction in high-income Japan and New Zealand after their 2011 earthquakes - the recovery process in Sri Lanka was much faster. The recovery processes from these other events were much slower and are, in fact, still incomplete.

But beyond the need for ample funds, the desire for speedy reconstruction is clearly in conflict with the desire to consult and seek participation from the affected local communities. In addition, the 
quest for speed is typically in conflict with the careful consideration of all possible development, planning, and reconstruction paths. Many of these alternative paths require significant planning effort. Most often, and most challenging, is the need to reallocate property rights for certain assets, the most difficult of which is land. These are challenging endeavors, and that is clearly part of the reason why speed is a lower priority in many reconstruction projects. Hence, the trade-off between speed and carefully planned reconstruction seems undeniable, but it is still worthwhile simply to note that, ceteris paribus, speed should be prioritized. A slow recovery makes it more difficult to achieve a BBB recovery.

\section{Build Back Fair}

A recovery that is fair and inclusive-that is, one that benefits all segments of the affected population-is yet another apparent and obvious objective. In this connection, a plethora of research studies find that recoveries frequently exclude the most vulnerable, disadvantaged, and poorest population segments (for a survey, see Karim and Noy 2016). Given the large amount of evidence of noninclusive recoveries, public planning for BBB needs to explicitly and systematically incorporate ways to mitigate this risk by including the weakest segments of society in the postdisaster reconstruction process. This aim needs a conscious and sustained effort in that direction, since reaching the most disadvantaged and vulnerable is not necessarily "speedy." Without a well targeted focus, the hectic and often chaotic process of reconstruction is liable to leave the poor behind.

\section{Build Back Potential}

Beyond fair, fast, and safe, postdisaster recovery should also aim to generate future growth opportunities. Without economic opportunities, the quality of life and well-being deteriorates (e.g., Sen 2000, Friedman 2006). A fair, fast, and safe recovery does not necessarily translate into greater economic potential and opportunities for the reconstructed city or community. A cautionary tale comes from the city of Kobe, which experienced fast, safe, and most likely inclusive reconstruction but suffered a decline in economic opportunities and thus its long-term economic fortunes (duPont et al. 2015). Policy makers at all levels should be thinking of reconstruction that promotes economic opportunities and economic dynamism. Without renewed economic potential, a BBB recovery will not be sustainable, and is unlikely to be safe nor fair.

To conclude, the four basic criteria for assessing the effectiveness of any BBB effort should be safety, speed, inclusiveness, and long-term economic potential. One of these criteria may sometimes come into conflict with another criterion. Nevertheless, the four objectives do provide a rough concrete checklist for planning BBB. Neglecting any of the criteria would seriously jeopardize the ultimate objective of building strong and resilient communities that are better able to cope with and bounce back from future disasters associated with natural hazards. At a minimum, safety, speed, fairness, and long-term economic potential would give policy makers a clearer and more concrete strategic guidance than the well-intentioned but vague and ill-defined "build back better" slogan. The lack of clarity and concreteness matters, since it impedes the strategic direction of the recovery process at the very outset. Finally, there is plenty of scope for further research on the long-term effects of disasters, a topic which, as noted earlier, remains poorly understood and underanalyzed despite its large economic, social, and human ramifications for disaster zones. 


\section{REFERENCES}

Aldrich, Daniel. 2012. Building Resilience. Chicago: University of Chicago Press.

Asian Development Bank (ADB). 2008. TA7081-PRC "People's Republic of China: Providing Emergency Response to Wenchuan Earthquake.” Manila.

Becchetti, Leonardo, Stefano Castriota, and Pierluigi Conzo. 2017. "Disaster, Aid, and Preferences: The Long-Run Impact of the Tsunami on Giving in Sri Lanka." World Development 94: 157-73.

Belloc, Marianna, Francesco Drago, and Roberto Galbiati. 2016. "Earthquakes, Religion, and Transition to Self-Government in Italian Cities." Quarterly Journal of Economics 131 (4): 1875-926.

Best, Rohan, and Paul J. Burke. 2019. "Macroeconomic Impacts of the 2010 Earthquake in Haiti." Empirical Economics 56 (5): 1647-81.

Boustan, Leah Platt, Matthew Kahn, and Paul Rhode. 2012. "Moving to Higher Ground: Migration Response to Natural Disasters in the Early Twentieth Century." American Economic Review 102 (3): 238-244.

Boustan, Leah Platt, Matthew Kahn, Paul Rhode, and Maria Lucia Yanguas, 2017. "The Effect of Natural Disasters on Economic Activity in U.S. Counties: A Century of Data.” NBER Working Paper No. 23410. Cambridge: National Bureau of Economic Resources.

Callen, Michael, 2015. "Catastrophes and Time Preference: Evidence from the Indian Ocean Earthquake." Journal of Economic Behaviour and Organization 118: 199-214.

Carroll, Lewis. 1856. Alice's Adventures in Wonderland. Peterborough, Ontario: Broadview Press.

Caruso, German, Sebastian J. Miller. 2015. "Long Run Effects and Intergenerational Transmission of Natural Disasters: A Case Study on the 1970 Ancash Earthquake." Journal of Development Economics 117: 134-50.

Caruso, German. 2017. "The Legacy of Natural Disasters: The Intergenerational Impact of 100 Years of Disasters in Latin America.” Journal of Development Economics 127: 209-33.

Cas, Ava Gail, Elizabeth Frankenberg, Wayan Suriastini, and Duncan Thomas. 2014. "The Impact of Parental Death on Child Well-Being: Evidence from the Indian Ocean Tsunami.” Demography 51 (2): 437-57.

Cassar, Alessandra, Andrew Healy, and Carl von Kessler. 2017. "Trust, Risk, and Time Preferences after a Natural Disaster: Experimental Evidence from Thailand.” World Development 94: 90-105.

Cavallo, Eduardo, Sebastian Galiani, Ilan Noy, and Juan Pantano. 2013. "Catastrophic Natural Disasters and Economic Growth.” Review of Economics and Statistics 95 (5): 1549-61.

Coffman, Makena, and Ilan Noy. 2012. "Hurricane Iniki: Measuring the Long-Term Economic Impact of a Natural Disaster Using Synthetic Control." Environment and Development Economics 17 (2): 187-205. 
Cole, Matthew A., Robert J.R. Elliott, Toshihiro Okubo, and Eric Strobl. 2019. "Natural Disasters and Spatial Heterogeneity in Damages: The Birth, Life and Death of Manufacturing Plants." Journal of Economic Geography 19 (2): 373-408.

Cuaresma, Jesus Crespo, Jaroslava Hlouskova, and Michael Obersteiner. 2008. "Natural Disasters as Creative Destruction? Evidence from Developing Countries.” Economic Inquiry 46 (2): 214-26.

Currie, Janet, and Maya Rossin-Slater. 2013. "Weathering the Storm: Hurricanes and Birth Outcomes." Journal of Health Economics 32 (3): 487-503.

De Alwis, Diana. 2018. "Distributional Impacts of Disaster Recovery: Sri Lankan Households a Decade after the 2004 Indian Ocean Tsunami." School of Economics and Finance Working Paper 5/2018. Wellington: Victoria University.

De Alwis, Diana, and Ilan Noy. 2019. "Sri Lankan Households a Decade after the Indian Ocean Tsunami." Review of Development Economics 23 (2): 1000-26. https://onlinelibrary.wiley.com/ doi/abs/10.1111/rode.12586.

Dell, Melissa, Benjamin F. Jones, and Benjamin A. Olken. 2014. "What Do We Learn from the Weather? The New Climate-Economy Literature.” Journal of Economic Literature 52 (3): 74098.

Deryugina, Tatyana, Laura Kawano, and Steven Levitt. 2018. "The Economic Impact of Hurricane Katrina on Its Victims: Evidence from Individual Tax Returns." American Economic Journal: Applied Economics 10 (2): 202-33.

duPont, William IV, and Ilan Noy. 2015. "What Happened to Kobe? A Reassessment of the Impact of the 1995 Earthquake in Japan." Economic Development and Cultural Change 63 (4): 777-812.

2018. "The Long-Term Consequences of Natural Disasters: What Do We Know, and What We Still Don't.” International Review of Environmental and Resource Economics 12 (4): 325-54.

duPont, William IV, Ilan Noy, Yoko Okuyama, and Yasuyuki Sawada. 2015. "The Long-Run SocioEconomic Consequences of a Large Disaster: The 1995 Earthquake in Kobe.” PLoS ONE 10 (10).

Dussaillant, Francisca, and Eugenio Guzmán. 2014. "Trust via Disasters: The Case of Chile's 2010 Earthquake." Disasters 38 (4): 808-32.

Felbermayr, Gabriel, and Jasmin Gröschl. 2014. "Naturally Negative: The Growth Effects of Natural Disasters.” Journal of Developing Economics 111: 92-106.

Fomby, Thomas, Yuki Ikeda, and Norman Loayza. 2013. "The Growth Aftermath of Natural Disasters.” Journal of Applied Econometrics 28 (3): 412-34.

Friedman, Benjamin M. 2006. The Moral Consequences of Economic Growth. New York: Penguin Random House. 
Government of the People's Republic of China. 1999-2018. National Bureau of Statistics of China. http://www.stats.gov.cn/english/Statisticaldata/AnnualData/ (accessed 12 October 2018).

Government of Sri Lanka. 1974-2017. National Summary Data Page. Central Bank of Sri Lanka. https://www.cbsl.gov.lk/en/statistics/data/special-data-dissemination-standard (accessed 10 December 2018).

- - - 2002. Census of Population. Department of Census and Statistics. http://www.statistics.gov.lk/ (accessed 12 October 2018).

- - - 2005. Report on Impact of Tsunami 2004 on Sri Lanka. Department of Census and Statistics. http://www.statistics.gov.lk/tsunami/census/Summarynew.pdf.

- - 2015. National Accounts. Department of Census and Statistics. http://www.statistics.gov.lk/page.asp?page=National\%20Accounts (accessed 12 October 2018).

Groen, Jeffrey A., and Anne E. Polivka. 2010. "Going Home after Hurricane Katrina: Determinants of Return Migration and Changes in Affected Areas." Demography 47 (4): 821-44.

Gröger, André, and Yanos Zylberberg. 2016. "Internal Labor Migration as a Shock Coping Strategy: Evidence from a Typhoon." American Economic Journal: Applied Economics 8 (2): 123-53.

Hallegatte, Stéphane, Jun Rentschler, and Brian Walsh. 2018. Building Back Better: Achieving Resilience through Stronger, Faster, and More Inclusive Post-Disaster Reconstruction. Washington, DC: World Bank.

Halliday, Timothy J. 2012. "Intra-Household Labor Supply, Migration, and Subsistence Constraints in a Risky Environments: Evidence from El Salvador.” European Economic Review 56 (6): 1001-19.

Hanlon, W. Walker. 2017. "Temporary Shocks and Persistent Effects in Urban Economies: Evidence from British Cities after the U.S. Civil War.” Review of Economics and Statistics 99 (1): 67-79.

Hettige, Siri, and Richard Haigh. 2016. "An Integrated Social Response to Disasters: The Case of the Indian Ocean Tsunami in Sri Lanka." Disaster Prevention and Management 25 (5): 595-610.

Hino, Miyuki, Christopher B. Field, and Katharine J. Mach. 2017. "Managed Retreat as a Response to Natural Hazard Risk.” Nature Climate Change 7: 364-70.

Hornbeck, Richard. 2012. "The Enduring Impact of the American Dust Bowl: Short- and Long-Run Adjustments to Environmental Catastrophe.” American Economic Review 102 (4): 1477-507.

Hornbeck, Richard, and Daniel Keniston. 2017. "Creative Destruction: Barriers to Urban Growth and the Great Boston Fire of 1872." American Economic Review 107 (6): 1365-98.

Hornbeck, Richard, and Suresh Naidu. 2014. "When the Levee Breaks: Black Migration and the Economic Development in the American South." American Economic Review 104 (3): 963-90. 
Husby, Trond, Henri de Groot, Marjan Hofkes, and Martijn Dröes. 2014. "Do Floods Have Permanent Effects? Evidence from the Netherlands.” Journal of Regional Science 54 (3): 355-77.

International Monetary Fund. 1948-2018. International Financial Statistics. https://data.imf.org/IFS (accessed 12 October 2018).

Jayasuriya, Sisira, and Peter McCawley. 2010. The Asian Tsunami: Aid and Reconstruction after a Disaster. Edward Elgar Publishing.

Karim, Azreen, and Ilan Noy. 2016. "Poverty, Inequality and Natural Disasters - A Qualitative Survey of the Empirical Literature.” Singapore Economic Review 61 (1): 1-36.

Kennedy, Jim, Joseph Ashmore, Elizabeth Babister, and Ilan Kelman. 2008. "The Meaning of 'Build Back Better': Evidence from Post-Tsunami Aceh and Sri Lanka." Journal of Contingencies and Crisis Management 16 (1): 24-36.

Kikuta, Kyosuke. 2018. "Postdisaster Reconstruction as a Cause of Intrastate Violence: An Instrumental Variable Analysis with Application to the 2004 Tsunami in Sri Lanka." Journal of Conflict Resolution 63 (3): 760-85.

Kishore, Nishant, Domingo Marqués, Ayesha Mahmud, Mathew V. Kiang, Irmary Rodriguez, Arlan Fuller, Peggy Ebner, Cecilia Sorensen, Fabio Racy, Jay Lemery, Leslie Maas, Jennifer Leaning, Rafael A. Irizarry, Satchit Balsari, and Caroline O. Buckee. 2018. "Mortality in Puerto Rico after Hurricane Maria." The New England Journal of Medicine 379 (2): 162-70.

Klomp, Jeroen, and Kay Valckx. 2014. "Natural Disasters and Economic Growth: A Meta-Analysis." Global Environmental Change 26: 183-95.

Landry, Craig E., Okmyung Bin, Paul Hindsley, John C. Whitehead, and Kenneth Wilson. 2007. "Going Home: Evacuation-Migration Decisions of Hurricane Katrina Survivors." Southern Economic Journal 74 (2): 326-43.

Lazzaroni, Sara, and Peter van Bergeijk. 2014. "Natural Disasters' Impact, Factors of Resilience and Development: A Meta-analysis of the Macroeconomic Literature." Ecological Economics 107: 333-46.

Loayza, Norman, Eduardo Olaberria, Jamele Rigolini, and Luc Christiaensen. 2012. "Natural Disasters and Growth: Going beyond the Averages.” World Development 40 (7): 1317-36.

Luo, Kevin, and Tomoko Kinugasa. 2018. "Do Natural Disasters Influence Long-Term Saving? Assessing the Impact of the 2008 Sichuan Earthquake on Household Saving Rates Using Synthetic Control.” Discussion Paper 1804. Graduate School of Economics, Kobe University.

McDermott, Thomas K.J. 2012. "The Effects of Natural Disasters on Human Capital Accumulation.” Institute for International Immigration Studies Discussion Paper No. 391. Trinity College Dublin.

Mill, John Stuart. 1896. Principles of Political Economy. New York: D. Appleton. 
Morita Tomohiro, Shuhei Nomura, Masaharu Tsubokura, Claire Leppold, Stuart Gilmour, Sae Ochi, Akihiko Ozaki, Yuki Shimada, Kana Yamamoto, Manami Inoue, Shigeako Kato, Kenji Shibuya, and Masahiro Kami. 2017. "Excess Mortality Due to Indirect Health Effects of the 2011 Triple Disaster in Fukushima, Japan: A Retrospective Observational Study." Journal Epidemiol Community Health 71 (10): 974-80.

Organisation for Economic Co-operation and Development. Statistics. https://stats.oecd.org/. (accessed 12 October 2018).

Parida, Yashobanta, Devi Prasad Dash, Parul Bhardwaj, and Joyita Roy Chowdhury. 2018. "Effects of Drought and Flood on Farmer Suicides in Indian States: An Empirical Analysis." Economics of Disasters and Climate Change 2 (2): 159-80.

Park, Albert, and Sangui Wang. 2017. "Benefiting from Disaster? Public and Private Responses to the Wenchuan Earthquake.” World Development 94: 38-50.

Paul, Bimal Kanti. 2005. "Evidence against Disaster-Induced Migration: the 2004 Tornado in NorthCentral Bangladesh.” Disasters 29 (4): 370-85.

Raschky, Paul A. 2008. "Institutions and the Losses from Natural Disasters." Natural Hazards and Earth System Sciences 8 (4): 627-34.

Rush, John. 2018. "The Impact of Natural Disasters on Education in Indonesia." Economics of Disasters and Climate Change 2 (2): 137-58.

Sacerdote, Bruce. 2012. "When the Saints Go Marching Out: Long-Term Outcomes for Student Evacuees from Hurricanes Katrina and Rita." American Economic Journal: Applied Economics 4 (1): 109-35.

Sawada, Yasuyuki, and Satoshi Shimizutani. 2008. "How Do People Cope with Natural Disasters? Evidence from the Great Hanshin-Awaji (Kobe) Earthquake.” Journal of Money, Credit, and Banking 40 (2-3): 463-88.

Sawada, Yasuyuki, and Yoshito Takasaki. 2017. "Natural Disaster, Poverty, and Development: An Introduction." World Development 94 (C): 2-15.

Schultz, Jessica, and James R. Elliott. 2013. "Natural Disasters and Local Demographic Change in the United States.” Population and Environment 34 (3): 293-312.

Sen, Amartya. 2000. Development as Freedom. New York: Anchor Books.

Skidmore, Mark, and Hideki Toya. 2002. “Do Natural Disasters Promote Long-Run Growth?” Economic Inquiry 40 (4): 664-87.

Smith, Adam. 1776. An Inquiry into the Nature and Causes of Wealth of Nations. Chicago: University of Chicago Press. 
Smith, Stanley K., and Christopher McCarty. 1996. "Demographic Effects of Natural Disasters: A Case Study of Hurricane Andrew*." Demography 33 (2): 265-75.

Spencer, Nekeisha, Solomon Polachek, and Eric Strobl. 2016. "How Do Hurricanes Impact Scholastic Achievement? A Caribbean Perspective." Natural Hazards 84 (2): 1437-62.

World Bank. 1960-2018. World Development Indicators. Washington, DC. wdi.worldbank.org/ (accessed 12 October 2018).

Wu, Jidong, and Ning Li, and Wei Xie. 2012. "Interregional Economic Impact Analysis of the Wenchuan Earthquake, China.” https://www.iioa.org/conferences/20th/papers/files/795_ 20120430041_Wu_20thllOA.pdf.

Yamamura, Eiji. 2016. "Natural Disasters and Social Capital Formation: The Impact of the Great Hanshin-Awaji Earthquake." Papers in Regional Science 95 (S1): S143-S164.

Yonson, Rio, and Ilan Noy. 2018. "Measurement of Economic Welfare Risk and Resilience of the Philippine Regions.” CESifo Economic Studies Working Paper Series No. 6953. Oxford: Oxford University Press. 


\section{Build Back Better \\ What Is It, and What Should It Be?}

Long-term consequences of catastrophic disasters are poorly understood yet may be much more important than the short-term emergency phase. In contrast, policy literature is full of aspirational plans to "build back better" (BBB) - a recovery that leads to improvements above and beyond the predisaster status quo.

This paper presents two well-known BBB cases: (i) Sri Lanka after the 2004 Indian Ocean tsunami, and (ii) Sichuan province in the People's Republic of China after its 2008 earthquake. It proposes a more precise and concrete definition of economic BBB and recommends four criteria against which one should evaluate BBB: safety, speed, fairness (inclusiveness), and socioeconomic potential.

\section{About the Asian Development Bank}

$A D B$ is committed to achieving a prosperous, inclusive, resilient, and sustainable Asia and the Pacific, while sustaining its efforts to eradicate extreme poverty. Established in 1966, it is owned by 68 members -49 from the region. Its main instruments for helping its developing member countries are policy dialogue, loans, equity investments, guarantees, grants, and technical assistance. 